\title{
Urban infrastructure, climate change, disaster and risk: lessons from the past for the future
}

\author{
Robin Coningham and Lisa J. Lucero
}

\begin{abstract}
Narratives of lost cities and the exploration of ruins have captivated scholars and travellers for hundreds of years with explanations for their demise ranging from invasions to cataclysmic environmen-tal events. This article explores three case studies to consider the impact of climate change, disaster and risk on urban infrastructure in the past, as well as to reflect on potential lessons of adaptation and resil-ience for modern cities and their inhabitants. The first examines the degree to which historic urban infra-structure can tell us about seismic adaptation in pre-modern Nepal, as well as recognising the increasing challenges to vernacular architecture from climate change. The second, Sri Lanka's Medieval cities in the North Central Province, examines the intricate relationship between the ancient city of Anuradhapura and its artificial hydraulic landscape, a relationship which saw resilience defeated by irreversibly engi-neered adaptation. The final example is drawn from the experience of another tropical society on the other side of the globe, the low-density urban Classic Maya of Central America, which offers different yet relevant insights into alternate urban lifeways, both ancient and contemporary. Focusing on issues of successful and unsuccessful adaptations in urban settings over an archaeological time range and eval-uating how archaeologists and historians have explored and presented this evidence, we conclude by considering how archaeology and archaeologists can also play a greater role in future sustainable urban planning.
\end{abstract}

Keywords: climate change, urban infrastructure, disaster, risk, reliance, adaptation, pre-modern Nepal and Sri Lanka, earthquakes, tsunamis, historic infrastructure, the Classic Maya, path dependency, lessons learned.

Notes on the authors: see end of article.

\section{Introduction}

At the conclusion of the Fourteenth Summit of the South Asian Association for Regional Cooperation (SAARC) in 2007, the Presidents of Afghanistan, the Maldives and Sri Lanka; the Chief Adviser of the Government of Bangladesh; and the Prime Ministers of Bhutan, India, Nepal and Pakistan issued a declaration in which they:

(C) The author(s) 2021. This is an open access article licensed under a

Creative Commons Attribution-NonCommercial-NoDerivs 4.0 Unported License 
expressed deep concern over global climate change and the consequent rise in sea level and its impact on the lives and livelihoods in the region. They emphasised the need for assessing and managing its risks and impacts. They called for adaptation of initiatives and programmes; cooperation in early forecasting, warning and monitoring; and sharing of knowledge on consequences of climate change for pursuing a climate resilient development in South Asia. (Government of India 2007)

Followed by an action plan two years later, their commitment to understand adaptation, mitigation and policy was reiterated by the Rt Hon. Narendra Modi, India's Prime Minister at the start of 2021, when he stated that 'India's civilizational values teach us the importance of living in harmony with nature. Our ancient scripture Yajurveda teaches us that our relationship with planet earth is that of a mother and her child. If we take care of mother earth, she will continue to nurture us. To adapt to climate change, our lifestyles must also adapt to this ideal' (Government of India 2021).

These are significant statements as the South Asian leaders represent 21 per cent of the world's population and account for US\$3.67 trillion of its global economy (Figure 1). Their commitment also shows practical recognition of the long-term climatic threats facing SAARC members, which range from intensifying seasonal monsoons and droughts, sea level rise, salination, shrinking glaciers, floods and droughts in addition to short environmental shocks, such as earthquakes, landslides and tsunamis. The human cost of these threats is substantial. The Centre for Research on the Epidemiology of Disasters (CRED) has calculated that 98,660 deaths per million in India between 1994 and 2013 were directly attributable to natural disasters (2017: 27). To give an idea of the impact of a single recent disaster, the number of homes damaged by the 2015 Gorkha Earthquake has been reported as 8,300, in addition to 387 schools and 26 clinics and hospitals (CRED 2017: 34). Some of these threats are greater for some SAARC members than others. Bangladesh, for example, hosts a high population density (more than 1,209 people per square kilometre) and, in extreme years, more than two-thirds of the country can be inundated (OECD 2003: 16), leaving little opportunity for relocating populations and communities to safer locations. Indeed, during the 1998 floods, heavy rain and snowmelt in India and Nepal, and elevated tides in the Bay of Bengal, led to the inundation of 100,000 square kilometres and the displacement of 30 million people (OECD 2003: 18). In that report the Organisation for Economic Co-operation and Development (OECD) has also calculated that a one metre rise in sea level would inundate 18 per cent of Bangladesh's land mass and directly affect the livelihoods of 11 per cent of its population. Protection costs also test the state's ability to meet them as coastal defences would cost over a billion dollars, and it has been estimated that the cost of resettling 13 million people would be a further US\$13 billion (OECD 2003: 19). 


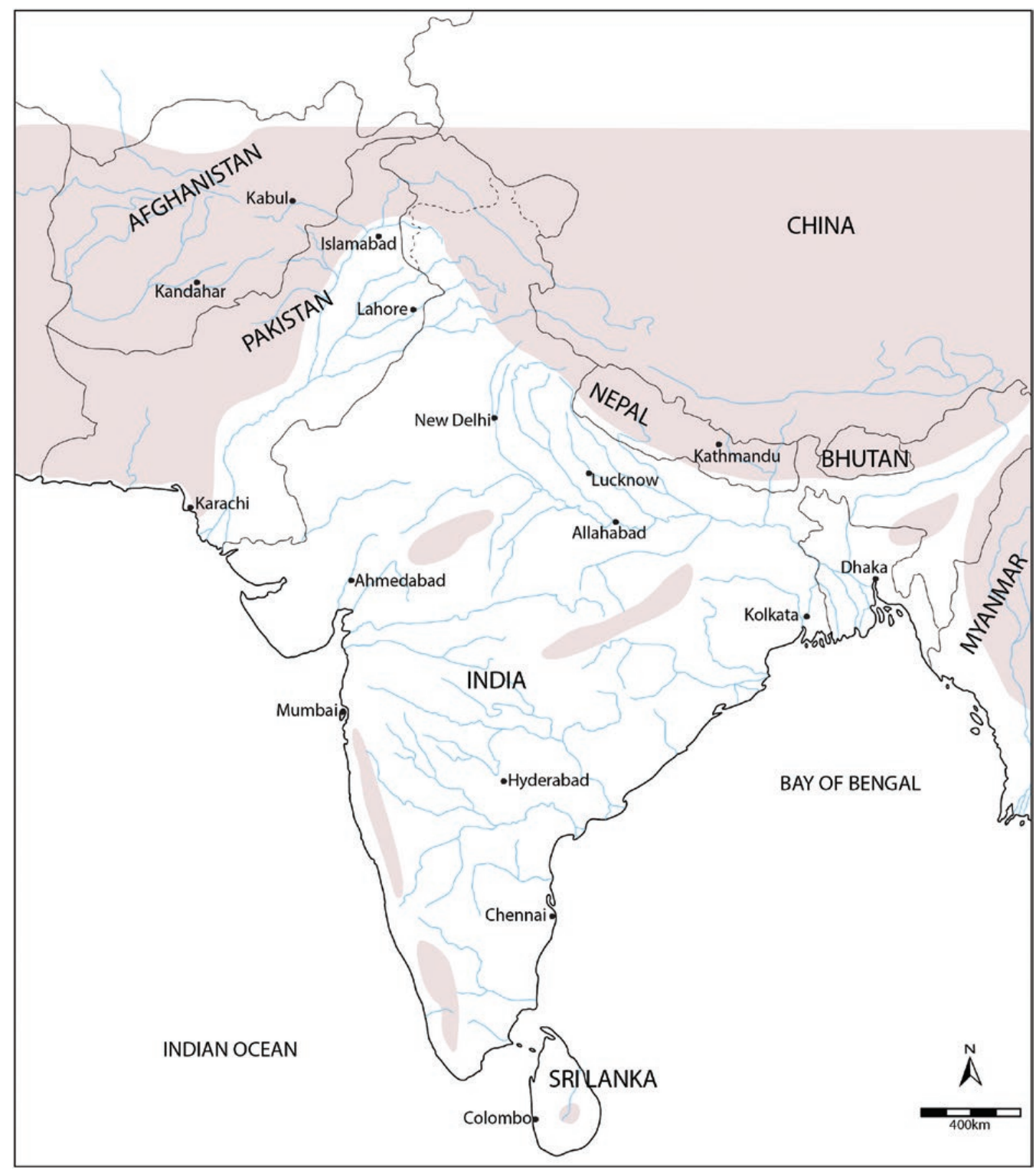

Figure 1. Map of South Asia showing modern nation states. (Image: Durham UNESCO Chair).

This brutal snapshot is shared across the globe's tropical belt, where 43 per cent of the global population resides and where 80 per cent of the world's terrestrial biodiversity is found (Harding \& Penny 2020: 13) (Figure 2). However, we acknowledge that details of the exact impacts of climate change on monsoonal and cyclonic patterns and intensity are extremely complex, particularly due to the nature of the existing limited time-series and fragmentary historical records. For the purposes of this article, we have adopted the United Nations' internationally accepted definitions of climate change, disaster and risk. Article 1.2 of the United Nations Framework Convention 
on Climate Change (UNFCCC) refers to climate change as 'a change in climate which is attributed directly or indirectly to human activity that alters the composition of the global atmosphere and which is in addition to natural climate variability observed over comparable periods of time' (UNFCCC 1995). Disasters are defined by the United Nations Office for Disaster Risk Reduction (UNDRR) as 'a serious disruption of the functioning of a community or a society at any scale due to hazardous events interacting with conditions of exposure, vulnerability and capacity, leading to one or more of the following: human, material, economic and environmental losses and impacts' (UNDRR 2021). Disaster risk is defined as 'The potential loss of life, injury, or destroyed or damaged assets which could occur to a system, society or a community in a specific period of time, determined probabilistically as a function of hazard, exposure, vulnerability and capacity' (UNDRR 2021). In this article, we will focus on issues of successful and unsuccessful adaptations in urban settings over an archaeological time range and evaluate how archaeologists and historians have explored and presented this evidence, before concluding by considering how archaeology and archaeologists can also play a greater role in future urban planning.

\section{Disasters, invasions, climate change, colonial and post-colonial histories in South Asia}

In the early centuries of British colonial exploration and imperial territorial expansion across South Asia in the 18th and 19th centuries CE, scholars attributed the fall and decline of the many deserted cities, monuments and settlements they encountered directly to human intervention, favouring invasions and migrations. As such, they echoed many of the explanations offered for such phenomena within Europe at that

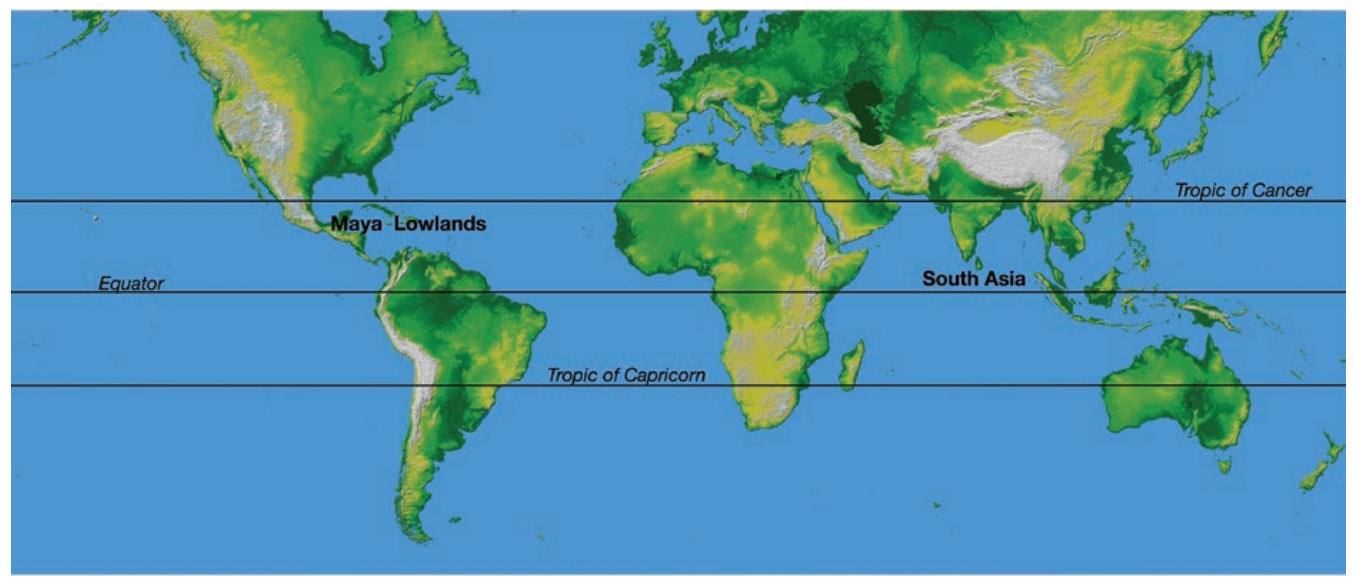

Figure 2. Map of the globe's tropical belt. (Image: L.J. Lucero). 
time (Chakrabarti 2000: 667). Certainly, migration was accepted by many, including the 18th-century philologist, Sir William Jones, who suggested that similarities between most north Indian languages and those of Iran and Europe were due to the fact 'that they all preceded from some central country' (Jones 1798: 431). While we may disregard some of the more fanciful suggestions of movements of Druids across South Asia (Chakrabarti 1976: 66), such explanations soon began to encourage a reliance on concepts of cultural diffusion to assist the process of mapping cultural sequences across South Asia. As explored elsewhere (Coningham \& Young 2015: 77-90), this began to promote a concept that South Asian cultural development was inherently passive until subject to external stimuli, or in the words of Mortimer Wheeler, a former Secretary of the British Academy, 'Indian prehistory ... displays, like the Indian landscape, wide expanses of uniformity ... But on the other hand, again like the Indian landscape, this monotony is broken by sudden changes and heights; ever and anon India leaps from its sleep and grasps new ideas, new opportunity, with quick and prehensile intelligence' (1963: 180). As a direct result, models forwarded by many archaeologists promoted external stimuli, as with D.H. Gordon's suggestion that the first cities of the Chalcolithic Indus Valley or Harappan Civilization (c.2600-1900 BCE) were Sumerian colonies (1960: 58), or Wheeler's own that South Asia's later Early Historic cities and states (c.600-185 BCE) were direct recipients of the Achaemenid Empire (1962: 13) (Figure 3). Despite rejections by a number of noted scholars at the time (Kosambi 1965: 138), many attached chronological lists of external influences within their site monographs (Marshall 1951: 83). It is also clear that these models passed quickly into common usage, as exemplified by the Christian missionary S.K. Dutta's The Desire of India, which stated that 'It is only when alien nations have touched the life of India that the veil is lifted and some accurate history becomes possible ... By a curious coincidence the story commences, just as it closes in our own day, with a European invasion', in reference to the eastern campaigns of Alexander the Great (1909: 113).

Perhaps unsurprisingly, a similar approach was adopted when explaining the decline of those same cities and states, perhaps most forcefully again by Wheeler. Combining evidence of a mass grave, foreign weapons and the general abandonment of the cities of the Indus Civilization by 1900 BCE, he famously accused the god Indra and an invasion of Aryans (Wheeler 1966: 78). Focusing on a later period, Sir John Marshall pursued a similar explanation by attributing the decline of the famous Early Historic city of Taxila on Pakistan's portion of the Silk Road, to an invasion of Hephthalites, also known as 'White Huns', in the 5th century CE. This long-serving Director-General of the Archaeological Survey of India cited evidence of skeletons and vandalised Buddhist monasteries and shrines, commenting that 'From this disaster Taxila never recovered' (1960: 39). Such explanations were not to be limited to the mainland as invasions from South India in the 10th and 11th centuries CE 


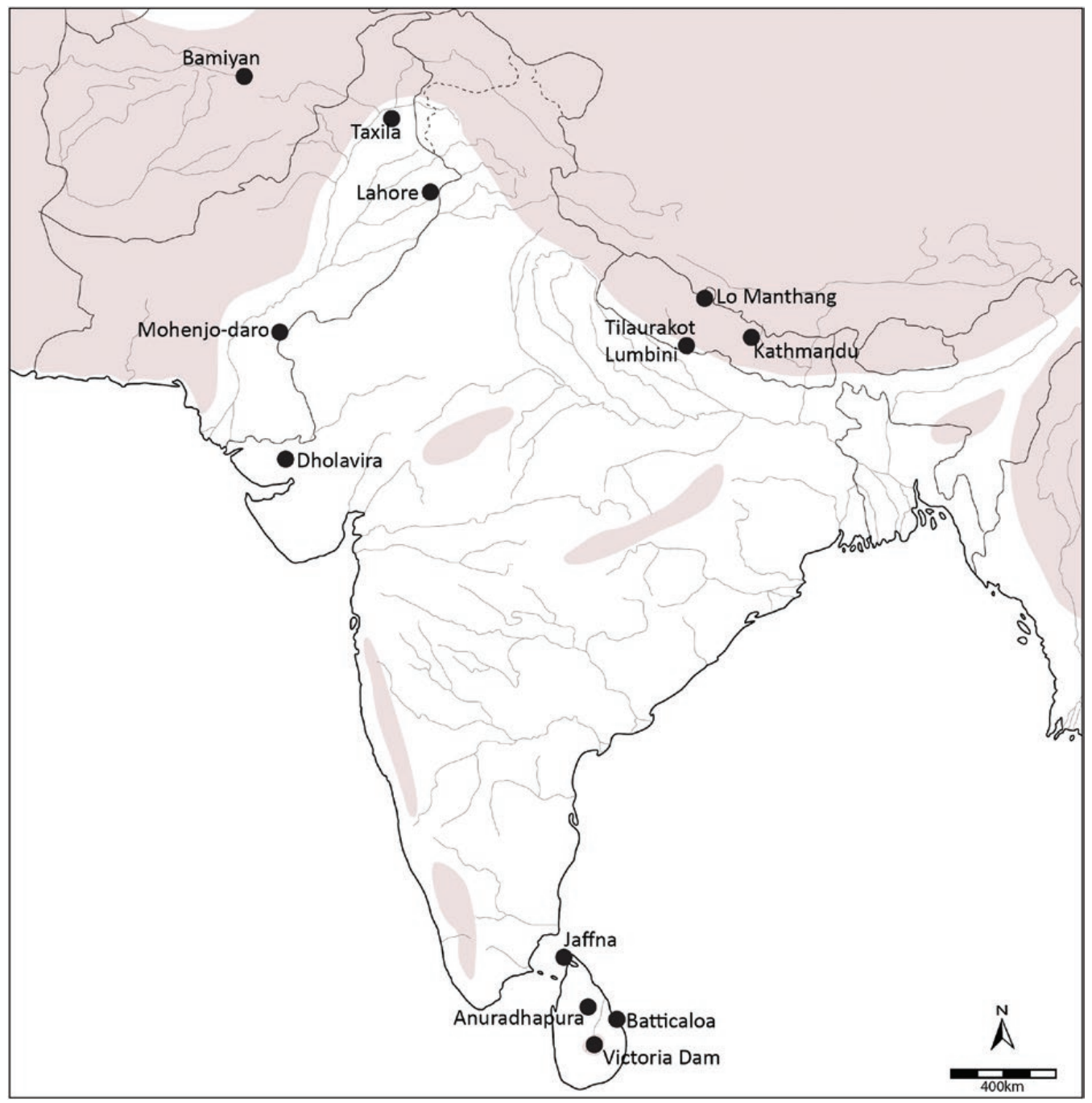

Figure 3. Map of key archaeological sites in South Asia. (Image: Durham UNESCO Chair).

were presented and accepted as explanations for the decline of the ancient capital of Anuradhapura in Sri Lanka, as well as the general abandonment of the Rajarata or 'King's Plain' around it (Codrington 1960: 94). Indeed, damaged Buddhist sculptures and monuments were frequently attributed to violence during the Chola Invasion and subsequent rule (Bell 1904: 7; Pieris 1925: 41) (Figure 4). Influenced by generations of British writers, even after the end of colonial rule (Gordon 1960: 35), explanations of cultural change through migration were also voiced by South Asian scholars in the post-colonial world (Banerjee 1965) and continue to remain popular (Seneviratna 1994: 34).

This is not, of course, to suggest that all international scholars or South Asian researchers were persuaded by such explanations. Indeed, with the increasing use of 
absolute chronometric dating, and the spread of processual archaeology through the 'New Archaeology' movement, many were more than willing to seek alternative explanations for the creation and destruction of cities and states. As might be anticipated, most opted to continue favouring a single prime mover but, this time, selected longer term climatic change and short environmental shocks. For example, when George Dales rejected the proposal that massacres by Aryan invasions had delivered a swift end to the Indus city of Mohenjo-daro, he proposed instead that tectonic events had led to recurrent floods, preventing its inhabitants from sowing or harvesting crops (1966). This was, in turn, countered by Lambrick, who instead suggested that avulsions and a major change in the course of the Indus River and its tributaries had resulted in the annual inundation of silt elsewhere, leading to the city's abandonment as its inhabitants sought to cultivate closer to the fresh silt, intensified by the increasing presence of salination (1967: 483). Explanations based on the impacts on short environmental shocks have continued to prove popular. For example, the end of the Indus port of Lothal in western India has been attributed to floods (Rao 1973: 59) and it has

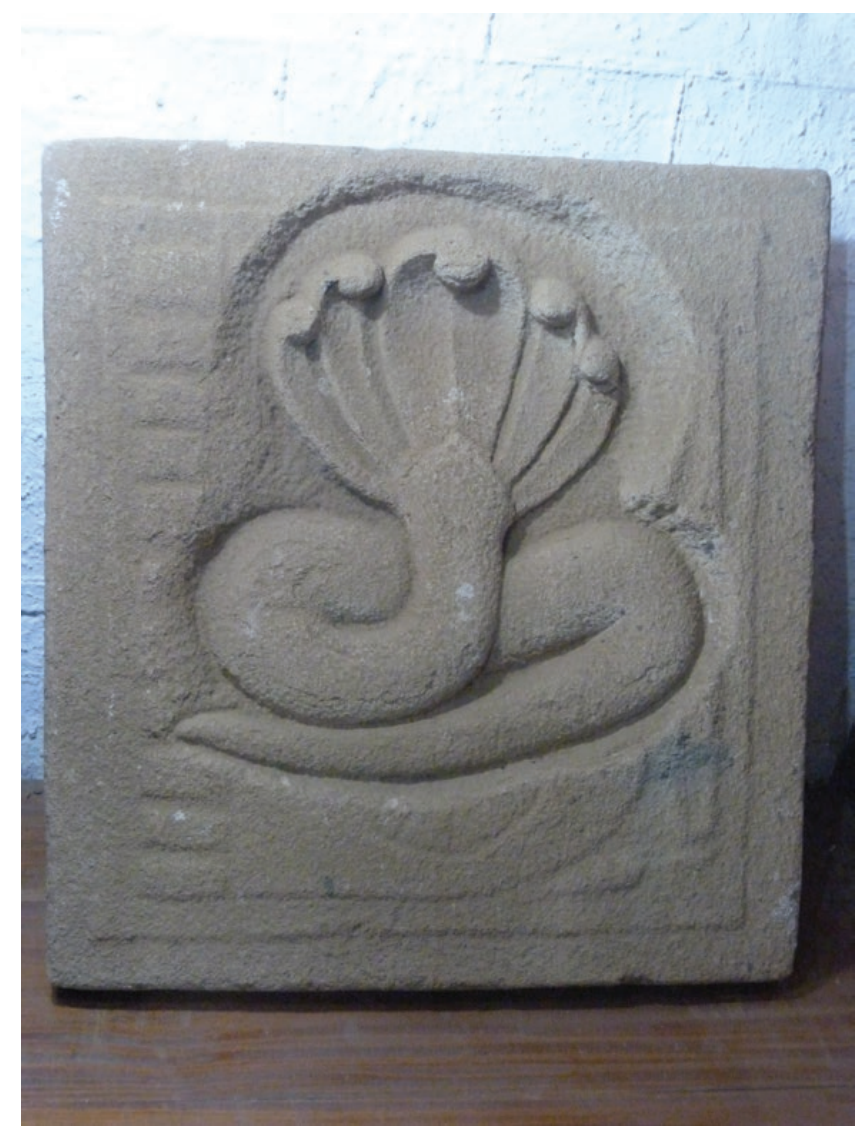

Figure 4. View of Buddha footprints recarved with a Naga in Jaffna Museum, Sri Lanka. (Image: Durham UNESCO Chair). 
been recently suggested that the walls of the Indus city of Dholavira were designed to protect it against sporadic tsunamis (Nigam et al. 2016: 2043). While debate still surrounds fabled cultural losses associated with the submergence of the lost continent of Lemuria in the Indian Ocean (Ramaswamy 2000: 576), there is increasing acceptance that reliance on a single factor is over-simplistic and untenable (Coningham \& Young 2015: 274). Indeed, Madella \& Fuller have observed that 'While many archaeologists have long argued against a climatic cause for the end of Harappan urbanism, this notion persists in some Quaternary science literature' (2006: 1298). More nuanced scenarios are now being generated, explanations which acknowledge that climatic change, resulting in a decline in rainfall, actually contributed to the emergence of urban agglomerations, as 'ever more intensive agriculture and control of surpluses, which buffered inter-annual shortfall, contributed to urban centralisation' (Madella \& Fuller 2006). In that paper, the authors acknowledged that the same climatic change could also have contributed to its later decline, as 'more diversified and extensive agriculture provided strategic risk buffering for smaller, local groups and could have contributed to social changes that ultimately resulted in the restructuring of the urban Harappan social system' (Madella \& Fuller 2006). A possible scenario in which a similar climate change can lead to two very different urban outcomes leaves us to conclude that, as already noted by Weiss (2016: 62), the key to societal survival lies in a community's ability to recognise the need to adapt and adjust their social and economic scaling and integration to meet longer-term trends.

\section{Climate change, disaster risk and resilience in Nepal}

As archaeology is a global discipline, these long-term theoretical trends are by no means unique to South Asia (see Middleton 2017; Diamond 2004; Tainter 1990). The present section examines the degree to which the study of historic urban infrastructure can tell us about successful historic adaptation in Nepal to an intermittent seismic environment, as well as recognising ways in which increasing challenges from climate change can be mitigated. The UNDRR has confirmed Nepal's position as the fourth in the world in terms of climate risk according to the Global Climate Risk Index as over 80 per cent of its 29 million population is exposed to earthquakes, droughts, floods, landslides, extreme temperature and glacier lake outburst floods (2019: 6). Since floods are an annual feature of the Terai in southern Nepal with devastating impacts, when designing the pilgrimage complex at the site of the Buddha's birth at Lumbini in the 1970s, Japanese architect Kenzo Tange created a circular pond levee around the site to protect the site and its visitors (Weise 2013: 133). This is not a novel phenomenon as evidence of flooding has been identified archaeologically at Lumbini's late Chalcolithic Village Mound (c.1300 BCE) (Strickland et al. 2016). Further evidence 
is apparent at the archaeological site of Tilaurakot-Kapilavastu, 27 kilometres to the west, where the Banganga River has clearly eroded the northwest corner of the 20 hectare walled city, which was occupied between the 8th century BCE and $1000 \mathrm{CE}$. Since then, the river has safely migrated westwards, but it is apparent that the ancient city's complex of ramparts, walls and moats played a role in mitigating the impact of flood water while benefiting from the settlement's close access to a major waterway (Davis et al. 2016). Settlement survey within the region has demonstrated a densely populated Early Historic landscape around the city with towns, shrines and villages, mostly clustered on fossil alluvial ridges, locations that demonstrate an awareness of the risk and mitigations (Verardi 2007: 57).

Although mitigating the impact of flooding with artificial barriers, while benefiting from the proximity of the rich agricultural landscape of the Terai, appears to have been a reasonable risk in the past, the construction of major tiered brick and timber monuments within the tectonic instability of the Kathmandu Valley seems less so. Clearly not an impact of climate change, the study of the Valley's architectural history within an extremely intermittent seismic environment provides a striking exemplar of human resilience and successful technical experimentation and adaptation. Indeed, it has been estimated that high magnitude earthquakes affect the Kathmandu Valley every hundred years or so with records of their devastation in 1224, 1255, 1260, 1344, 1408, 1681, 1767, 1823, 1833, 1834, 1869, 1916 and 1934 CE (Gautam et al. 2015: 1-3), making the survival of monuments over this time worthy of study. Despite their significance for lessons learned, while collateral damage to many of Kathmandu's historic structures was understandable during the emergency phase immediately following the 2015 Gorkha Earthquake as the dead and injured were recovered, professional concerns were raised that many historic structures and monuments had been irreversibly compromised and their foundations removed without recording during the subsequent clean up operations (Coningham et al. 2019). This destruction resulted in the loss of critical information concerning possible causes for the failure and collapse of individual buildings, as well as information concerning their successful seismic adaptation. In order to present an exemplar, a multi-disciplinary Nepali and international team drawn from the Government of Nepal's Department, the Nepal chapter of the International Council on Monuments and Sites (ICOMOS), Tribhuvan University, United Nations Educational, Scientific and Cultural Organization (UNESCO), University of Stirling, Newcastle University and Durham University's UNESCO Chair was mobilised to investigate the foundations of Kathmandu's eponymous monument, the Kasthamandap. Funding for the project's fieldwork, laboratory analysis and impact was provided by the Arts and Humanities Research Council (AHRC), UNESCO and the British Academy's Global Challenges Research Fund (GCRF) Cities and Infrastructure programme under the joint direction of Kosh Prasad Acharya and Robin Coningham, one of the present authors. 
An indistinct rubble mound after the earthquake, our rescue excavations at the Kasthamandap were able to examine the development of the ancient rest house's (shelter for travellers and traders) brick foundations as well as its timber superstructure (Figure 5). Our research programme was able to establish that the monument was some 500 years older than previously thought (Slusser \& Vajracharya 1974: 206) and had been initiated between the early 7 th and 9 th centuries CE (Coningham et al. 2021). This first phase comprised the construction of a massive 12 by 12 metre brick square formed by a two metre deep foundation wall set in a mud mortar, and four freestanding brick piers in the interior to support 5.6 metre high timber columns, each weighing more than a ton. Although radiocarbon dating has demonstrated that one of these original columns survived until the monument's tragic collapse in 2015, dates from the other three indicate that the monument was reconfigured and that the freestanding piers were braced by the introduction of a series of cross-walls following the apparent removal of all of the interior soil fills (Coningham et al. 2021). The solitary surviving wooden column was repaired and its lower tenon joint, which fitted into a stone saddlestone set above its corresponding brick pier, was replaced by a new wooden tenon dating to between the 11th and 12th centuries CE. In addition to this evidence of repair and maintenance, the new tenon was set within a copper shoe and the base of each of the four massive pillars separated from their respective saddlestones by sheets of copper. Artisans involved in the current reconstruction of the Kasthamandap have confirmed that this sheet had been purposely placed there to deteriorate as the resultant copper oxide retards both rot as well as termite infestations, indicating the strength of surviving indigenous knowledge networks (Coningham et al. 2019).

The interior of the monument, now comprising a nine-celled arrangement within the foundation wall, was then carefully refilled with what the project's geoarchaeologist Ian Simpson refers to as 'engineered soils' (Simpson 2021 pers. comm.), drawn from a number of very different sources (Figure 6). Subsequent analysis of the deposits by Simpson has suggested that they were purposely designed with a degree of liquefaction-proofing as they allowed the movement of water through them. Analyses of the mortars of the foundation wall also indicated that their sediment composition had a slightly raised non-swelling clay content, again indicating a degree of liquefaction-proofing (Coningham et al. 2019). The discovery of a nine-celled foundation at the Kasthamandap is not unique, as there have been reports of similar features within the Kathmandu Valley at Harigaon (Verardi 1988: 65). Giovanni Verardi noted that such a configuration is 'a mandala subdivided into nine padas ... one of the models envisaged in the traditional treatises on Newar architecture' (1988: 65). Furthermore, he recorded the

custom of constructing foundation walls with nine pits in a sacred building. ... After the prescribed ritual, the pits are filled with sand or earth. The ritual documented ... prescribes that in 


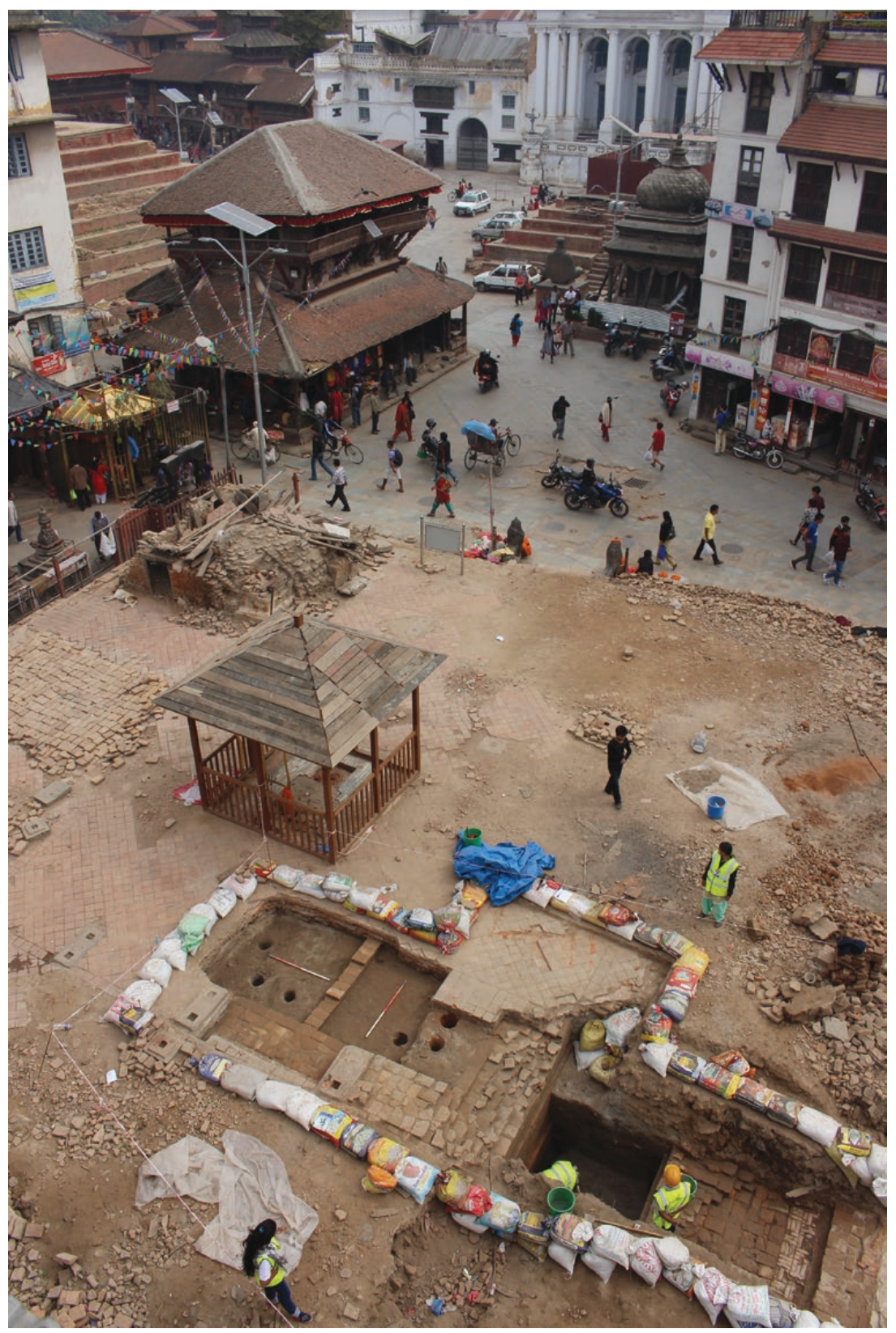

Figure 5. View of the collapsed Kasthamandap in Kathmandu after Nepal's 2015 Gorkha Earthquake. (Image: Durham UNESCO Chair).

each pit nine different kinds of grain are thrown. ... According to another recorded ritual, it is the powder of the pañcarangis, or 'five minerals' (gold, silver, copper, brass and iron) ... which is thrown in the kundas. The foundation of the sacred building, conceived and laid in the above way, is then sealed with a paved floor after having been consecrated. (1988: 6) 


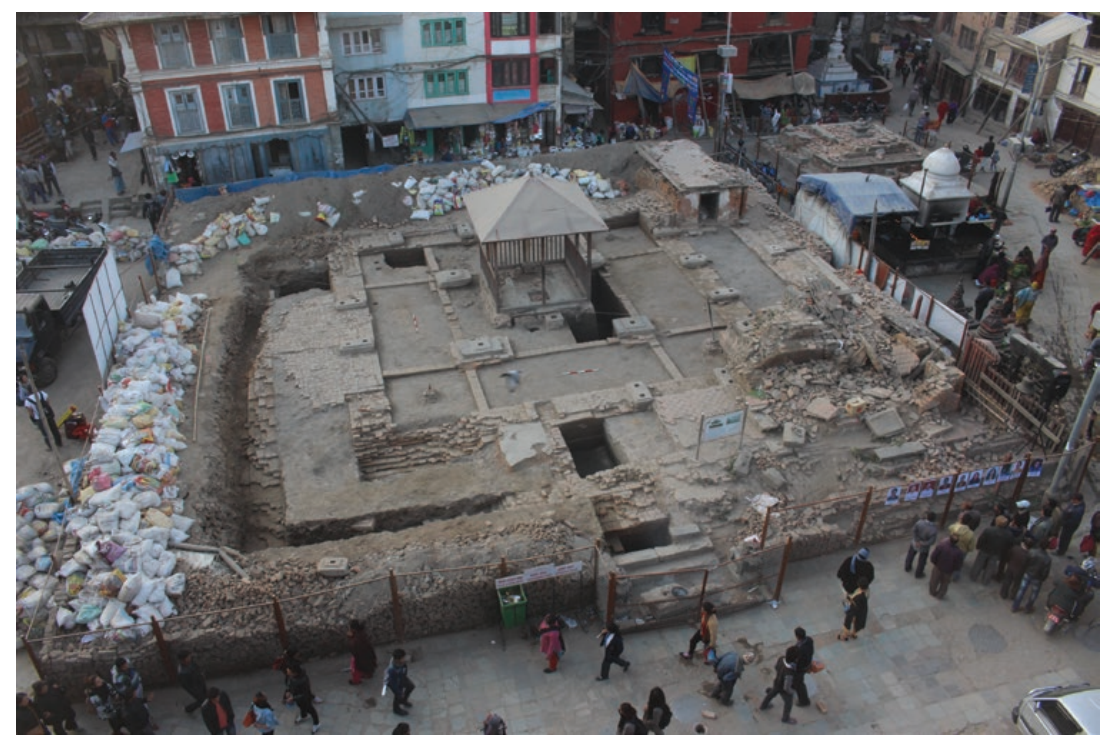

Figure 6. View of the nine-celled arrangement within the foundations of the Kasthamandap in Kathmandu, Nepal. (Image: Durham UNESCO Chair).

There is therefore the potential that these contemporary rites link to earlier practices of 'engineering soils' to provide a degree of liquefaction proofing; certainly there is barely any earthquake damage within the Kasthamandap's foundations (Davis et al. 2020).

These seismic adaptations of construction practice, combined with cycles of reconstruction and maintenance, provided a remarkable longevity for the monument of over a millennium until its collapse, an event accelerated by poor conservation interventions in the 1960s and 1970s. In addition to understanding more about historic and indigenous patterns of adaptation, renewal and maintenance, the post-disaster fieldwork also demonstrated that some of the Kathmandu Valley's environmental shocks had enabled the remodelling of urban space. For example, the currently open durbar or palace square in front of the former royal palace at Bhaktapur was once more hemmed in by structures. Following their failure, they were razed and paved over, which we were able to identify and map using Ground Penetrating Radar. Elsewhere, within Hanuman Dhoka's Durbar Square, we found evidence of levelled structures below the foundations indicating that Kathmandu's cityscapes were organic, reconfiguring over time, rather than conforming to a static plan (Coningham et al. 2018: 166). Indeed, earthquakes also provided opportunists the ability to appropriate monuments; our post-disaster excavations at the Jaisedewal Jaisi Deval were able to revise this structure's biography. Commonly attributed to the Minister Laksminarayana Josi in 1688 CE (Slusser 1982: 143), Optically Stimulated Luminescence dating of the monument's stepped plinths confirmed their late date, contemporary with Laksminarayana 
Josi, but the solid brick temple plinth core around which they had been constructed was originally erected in the 11th century CE, built by a patron now forgotten (Davis et al. 2020: 741).

While the impact of the 2015 Gorkha Earthquake damaged many historic structures across the Kathmandu, the longer-term challenges to Nepal's pre-modern cities from climate change are perhaps even greater. The use of flat mud roofs on major monuments within the trans-Himalayan Valley of Mustang in northern Nepal is, for example, extremely well adapted to the valley's predominantly dry climate and seasonal snow (Figure 7). However, increasing rainfall is resulting in leakage (Selter 2007: 69). While leakage can increase the likelihood of decay, more worryingly, it can also lead to waterlogging, which adds to the weight of the roof and threatens the stability of the rammed earth walls supporting it. While some residents have reportedly experimented with plastic sheeting, this intervention often increases moisture within the structures as they cannot 'breathe' and decay accelerates, threatening the stability of the monument. Now recognised as a particular challenge to the long-term survival of this unique category of monuments within Mustang's walled city of Lo Manthang, UNESCO is working with the Oriental Cultural Heritage Sites Protection Alliance and residents, to carefully analyse the causes of the deterioration of Lo Manthang's urban infrastructure: 'namely neglect, leakage, loss of know-how in masonry and carpentry and modern materials being preferred to traditional ones' (Richon 2019: 84) (Figure 8). In this case, local masons and carpenters are involved and are 'lifting misconceptions about modern materials and raising awareness of the pertinence of local materials' features and qualities, fighting water seepage through roofs and leakage through walls'. The community is now starting to 'test, build prototypes and document the best solutions and work in the longer term with local associations' (Richon 2019: 84). Combined, these examples demonstrate the need to recognise the value of indigenous knowledge with regard to risk reduction and to acknowledge that 'Build Back Better' concept, as presented within the 2015 Sendai Framework for Disaster Risk Reduction (United Nations 2015), should not necessarily be restricted to the deployment of modern materials and technologies.

\section{Disaster risk, adaptation and resilience in Medieval Sri Lanka}

Our second case study explores the historic challenges of developing mega-infrastructure to reduce disaster risk and enhance societal resilience in Medieval Sri Lanka. As noted above, colonial-era discoveries of the damaged Buddhist statues and monuments in northern Sri Lanka were frequently identified as evidence of south Indian invasions, as exemplified by the words of H.C.P. Bell, the first Archaeological Commissioner of Ceylon: 


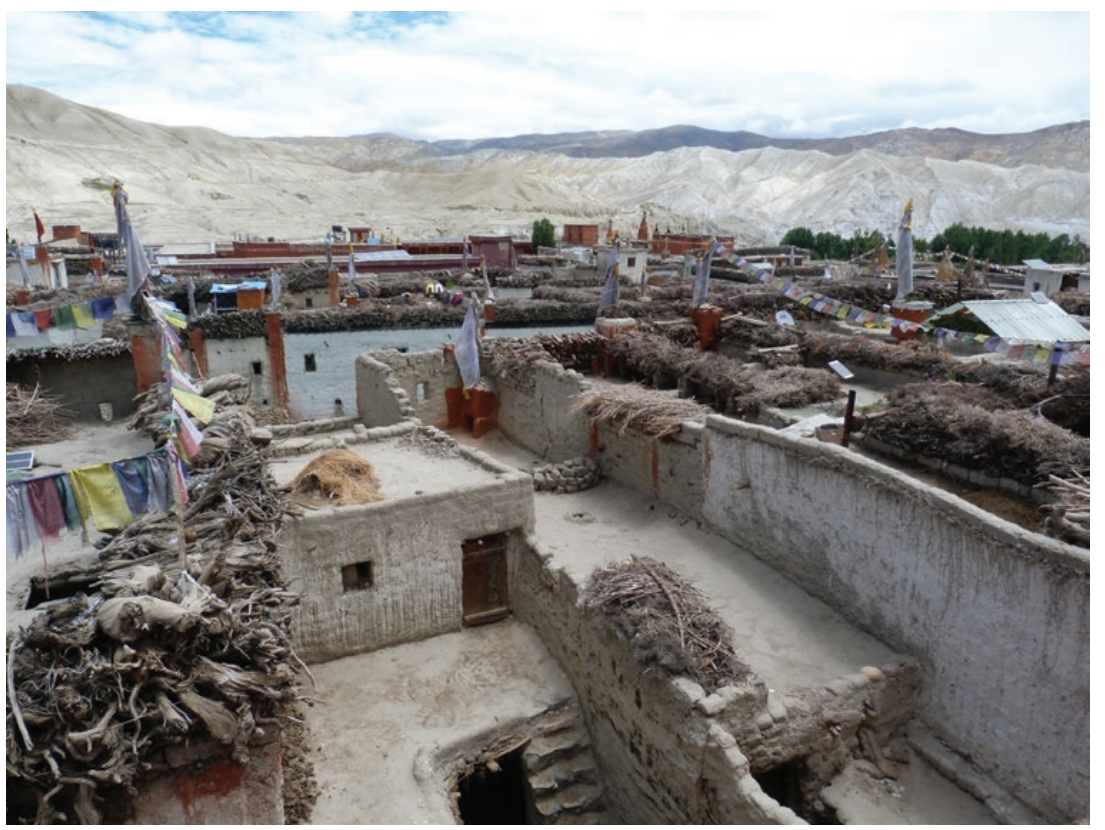

Figure 7. View of the flat mud roofs in upper Mustang, Nepal (Image: Durham UNESCO Chair).

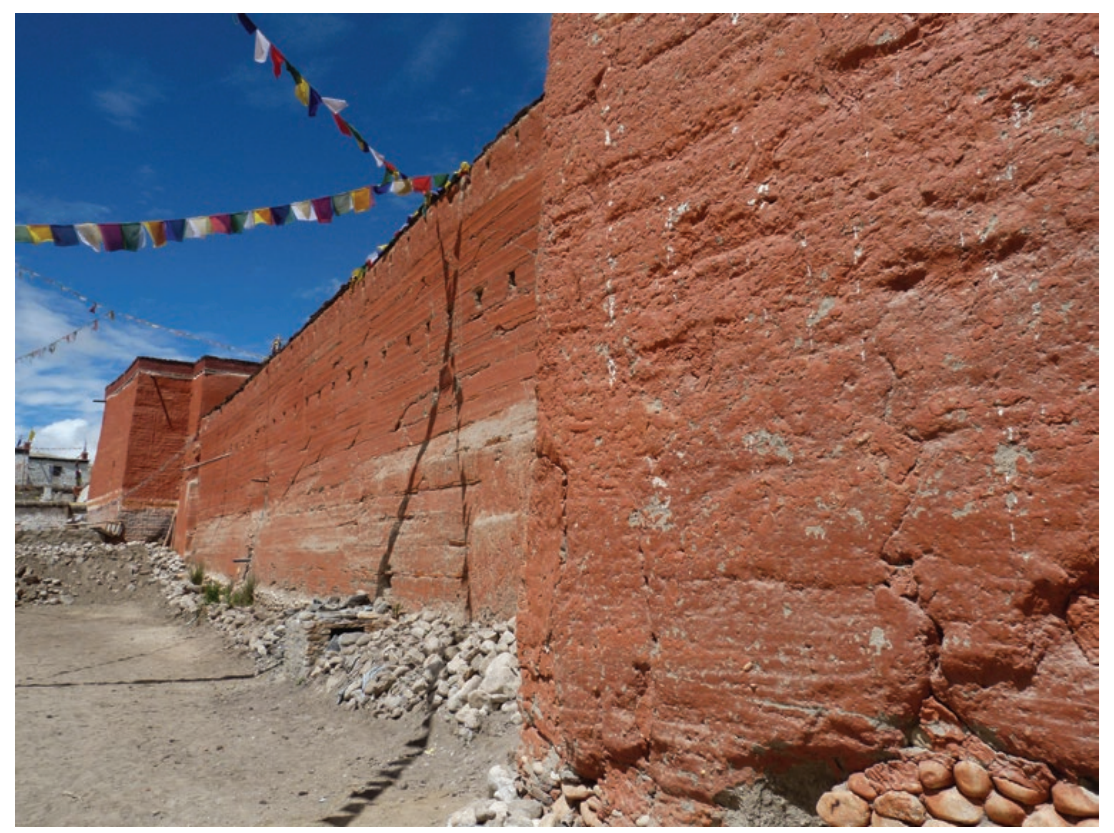

Figure 8. View of the rammed earth wall surrounding the city of Lo Manthang in Mustang, Nepal. (Image: Durham UNESCO Chair).

The indescribable confusion in which the fragments were found heaped one upon another, and the almost entire wreck of the railing, leave little room for doubt that this unique relic of Ceylon Buddhist architecture must have perished under the ruthless destruction of those invaders from 
South India at whose door lies the mutilation and ruin of the best works of the sculptor's art in Anuradhapura. (Bell 1904: 7)

Many post-independence scholars also attributed the demise and abandonment of the capital, Anuradhapura, to this human agency (Seneviratna 1994: 34), drawing heavily from the narratives compiled within the island's Mediaeval Mahavamsa Chronicle: 'Thereupon they sent the Monarch and all the treasures which had fallen into their hands at once to the Cola Monarch. In the three fraternities and in all Lanka (breaking open) the relic chambers, (they carried away) many costly images of gold etc., and while they violently destroyed here and there all the monasteries, like blood-sucking yakkhas they took all the treasures of Lanka for themselves' (Culavamsa 1927: 55.19.22). That the city, comprising a 100 hectare residential mound known as the Citadel and 25 square kilometre sacred city core of monastic complexes, was largely abandoned by the 11 th century $\mathrm{CE}$ is not questioned here but, rather, the explanations forwarded for its collapse (Strickland et al. 2018).

Before further examining the evidence for invasion, Anuradhapura's environmental setting is worthy of consideration as this massive urban complex is located in the island's Dry Zone, with an average rainfall of between 120 and 190 centimetres concentrated mainly between October and January. Adjacent to the largely seasonal river, the Malwattu Oya, the natural carrying capacity of the area is only 0.4 people per square kilometre (Coningham 1995). These stark figures provide a clear rationale for the massive human investment in the creation of a ring of large tanks or reservoirs around the city, ranging in size from the 1st century BCE Nuwarawewa, with a capacity of 42.5 million cubic metres, to the 3rd century BCE Tissawewa, with its 3.2 kilometre long dam (Coningham 1999) (Figure 9). To overcome the vagaries of localised rainfall, this system was later augmented by canals, such as the 87 kilometre long Yoda Ela, and storage tanks, such as the 2.23 square kilometre Kala Wewa, designed to tap into other headwaters. In the words of anthropologist Edmund Leach, this was "quite unquestionably an "hydraulic society"' (1959: 9). However, Leach also noted, as a number of scholars have, that this example of mega-infrastructure existed in parallel with a simple gravity-fed cascade system of rural tanks which supported the rural population (1959: 23).

While previous British Academy funded research to the late F.R. Allchin and Coningham had defined Anuradhapura's transition from Iron Age village to Indian Ocean metropolis (Coningham 1999, 2006), little attention had been paid to the rural communities sustaining it. In order to better understand their development, a multi-disciplinary team from the Universities of Durham, Bradford, Stirling and Leicester alongside the University of Kelaniya (Sri Lanka) and the University of Baroda (India), undertook the Anuradhapura Hinterland project, an AHRC-funded survey and excavation in the surrounding region between 2004 and 2008, directed 


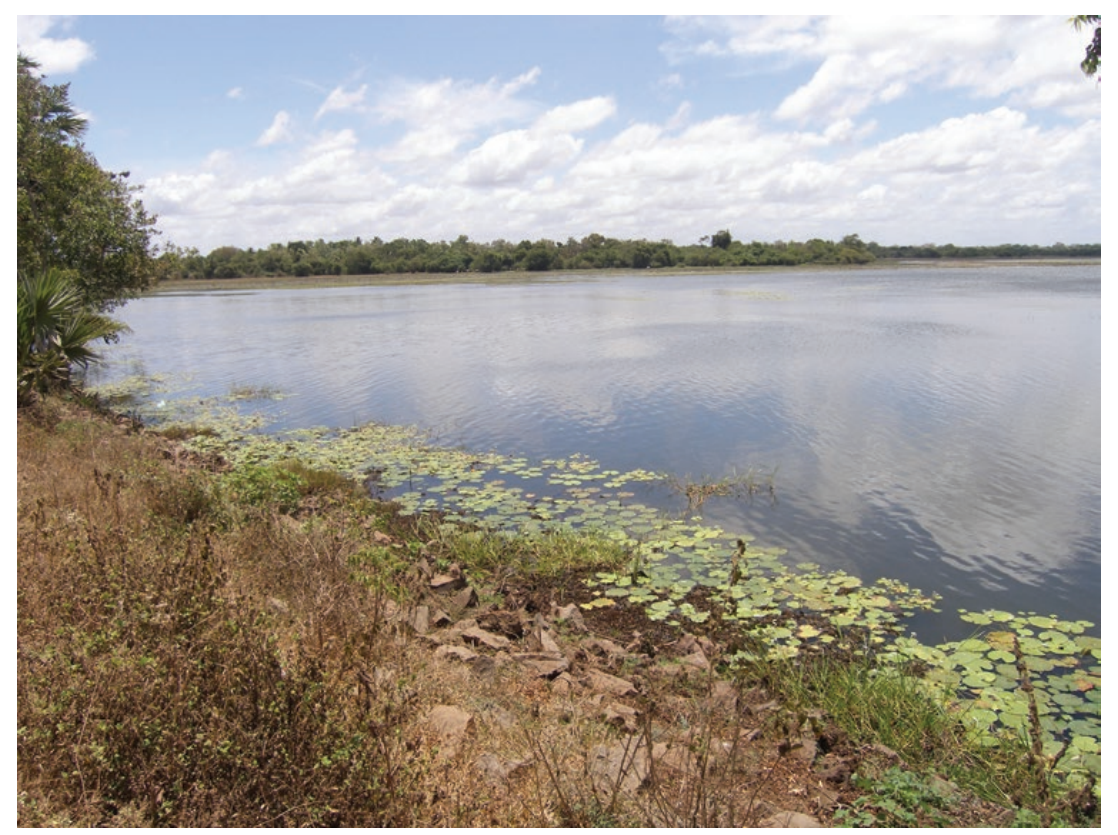

Figure 9. View of the 4th century BCE Basawak Kulam Tank in Anuradhapura, Sri Lanka. (Image: Durham UNESCO Chair).

by Prishanta Gunawardhana and Robin Coningham (Coningham \& Gunawardhana 2013) (Figure 10). Rather than finding evidence of a hierarchy of towns, villages and hamlets, as many have assumed populated the ancient landscape, the team identified a total of 754 sites forming a complex network of secular and religious heterarchies, linking the urban core and the rural hinterland. In this context, we term heterarchies as the potential simultaneous existence of multiple hierarchies (Coningham et al. 2007: 715 ), heterarchy being where 'each element possesses the potential of being unranked (relative to other elements) or ranked in a number of different ways' (Crumley 1979: 144). Indeed, there was little evidence of large-scale, secular towns in the hinterland, with Buddhist monasteries instead playing the role of administrators, centres of redistribution, and places of craft specialisation. However, it was also clear that Buddhism was not the only religion patronised within the hinterland, with the clear development of terracotta figurine cults and other practices running alongside more orthodox Buddhist monastic institutions (Coningham et al. 2012). These institutions, however, were clearly linked to the construction, management and maintenance of hydraulic systems that enabled agriculture to prosper and fed water to the city of Anuradhapura itself (Figure 11). This complex interchange between places of Buddhist worship, secular administration and centres of trade, termed 'Buddhist Temporalities', is unique within Early Historic South Asia (Davis \& Coningham 2018), but their patterns of settlement have now been recognised as sharing similarities with other tropical forest settings in Southeast Asia (e.g. Lansing 1991) and Central America. Following 


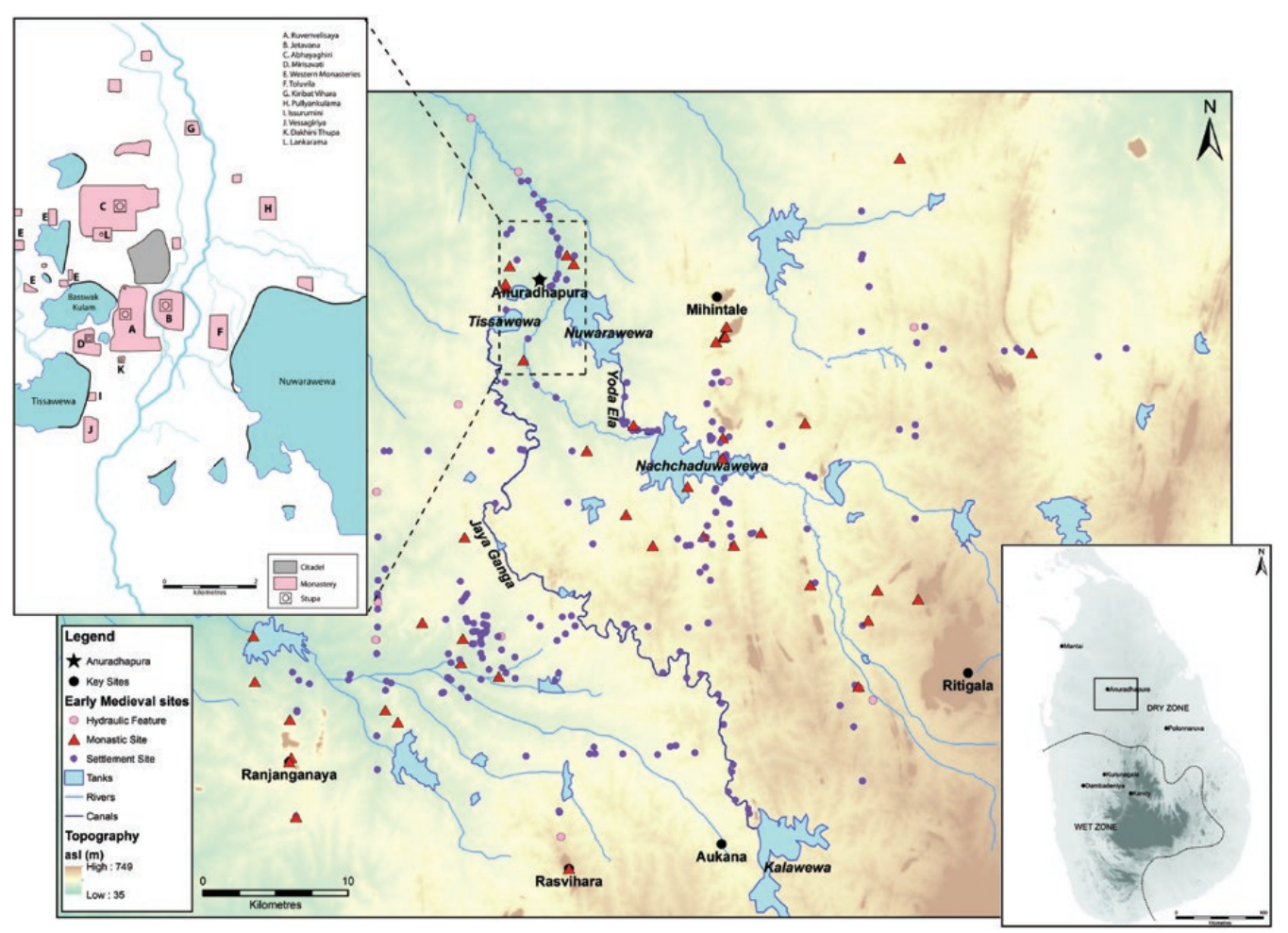

Figure 10. Map of archaeological sites identified during the Anuradhapura hinterland survey, Sri Lanka. (Image: Durham UNESCO Chair).

a Society for American Archaeology-Amerind Seminar in 2011 and a Wenner-Gren Conference in Angkor in 2012, attended by both Lucero and Coningham, we proposed the term 'low-density, dispersed agrarian urbanism' for this archaeological phenomenon in an article in the journal Antiquity (Lucero et al. 2015).

Although offering water for Anuradhapura's population, its livestock and irrigation agriculture for more than one and a half millennia, evidence for the 11th century CE decline of the city and its hinterland was also clearly identifiable. This included the abandonment of the Citadel, and smaller rural settlements, as well as evidence of the natural infill of irrigation works and water features (Gilliland et al. 2013: 203). This decline and lack of maintenance again can be related back to the initial function of Anuradhapura's mega-infrastructure, to provide water for people, animals and irrigation agriculture within a region where there was uneven seasonal rainfall. Undoubtedly, it also provided critical reserves for periods of drought, as well as managing surges from flash floods from cyclones and cloud bursts (Lucero et al. 2015: 1140). Augmented over the centuries, it was able to sustain a population as large as 200,000 (Coningham \& Manuel 2009) but, once constructed, the tanks and canals necessitated massive seasonal maintenance (Scarborough \& Burnside 2010). 


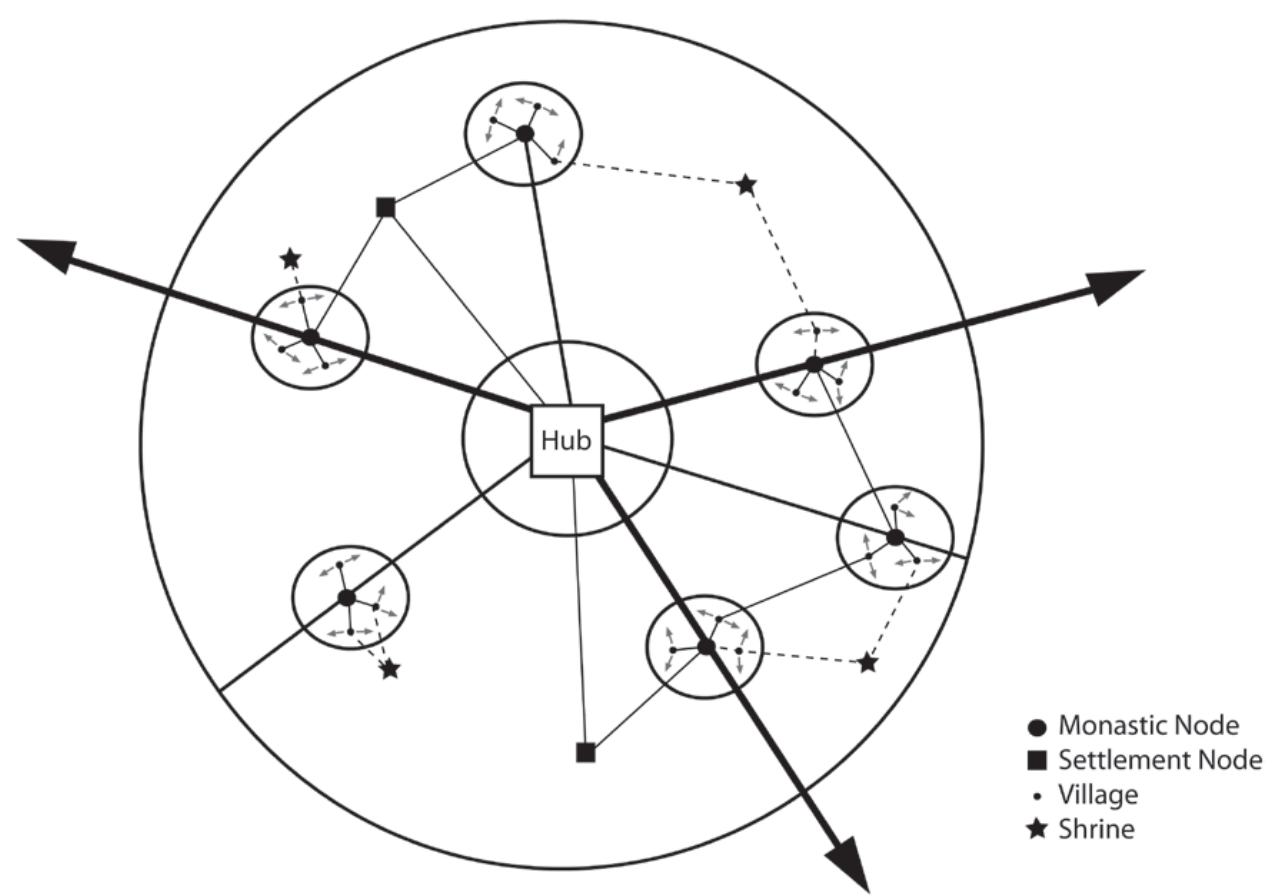

Figure 11. Schematic diagram of Anuradhapura's Medieval heterarchies, Sri Lanka. (Image: Durham UNESCO Chair).

Increasingly dependent and reliant on this configuration of 'increasingly elaborate, complex and intricately linked water systems' (Lucero et al. 2015: 1147), it appears that two interdependent features began to undermine its sustainability in the Early Medieval Period - access to labour and climatic instability. The first is traceable from the increasing number of inscribed stone pillars within the hinterland recording 'Immunity Grants' (Dias 2001: 113; Davis et al. 2013). These recorded the transfer of authority over large areas of land from royal officials to the Buddhist order but, critically, released its village communities from the traditional cycle of annual levee maintenance of royal infrastructure, including the tanks and canals which comprised the irrigation works (Gunawardana 1979: 97). This coincided with a sudden high-amplitude increase of the South West Monsoon, resulting in both severe drought and an increase in cyclonic storms within the North East Monsoon (Jung et al. 2004).

Whilst droughts could be mitigated through the tank and canal systems, the impact of cyclonic storms and their associated flash floods was far more challenging to manage. Indeed, a number of similar well recorded episodes within the last 50 years have demonstrated the magnitude of such impact. For example, the Batticaloa Cyclone of 1978 damaged more than 100,000 homes, killed almost 1,000 people, injured 4,500 more and damaged more than 90 per cent of the coconut crop and 60 per cent of planted rice paddies, while the 1957 storm damaged 35 major irrigation systems and 
1,300 village tanks (Srisangeerthanan et al. 2015: 295). Whilst such catastrophes are manageable by a modern country, with associated international interventions, it is clear that such events would be beyond the resources of most ancient states. Adaptation to the challenging environment of Anuradhapura proved to be irreversible and, as noted elsewhere, 'While the interlocking systems may initially have coped with changing circumstances, including climate extremes, they eventually failed' (Lucero et al. 2015: 1150).

In a contemporary environment where many donor agencies prefer to focus on mega-infrastructure, accepted by many erroneously as the acme of historical irrigation development, increasing numbers of reports suggest that such large-scale interventions may not be as beneficial as previously thought. For example, between 1979 and 1985, the UK government contributed $£ 117$ million towards the construction of the Victoria Dam in Sri Lanka's Hill Country to generate hydro-electric power as well as store additional water for downstream irrigation. However, in 1992 the UK's National Audit Office observed that the dam's power output had been reduced by 40 per cent due to reduced water availability and that 3,900 more families than initially planned had had to be resettled, and that 80 per cent of those 30,000 resettled were still dependent on food subsidies up to four years after its completion. Their report concluded that 'the project had not generated the UK commercial return envisaged' (NAO 1992: 30), a conclusion set against recent recognition of the smaller scale cascade systems of the Dry Zone as a sustainable measure of watershed management (Bebermeier et al. 2017). In this case study, bigger is not necessarily better.

\section{Disaster risk, resilience and the Classic Maya (c.250-900 CE)}

Our third and final case study explores how Classic Maya urban-rural interaction (URI) in the southern lowlands of present-day Belize, northern Guatemala and southeast Mexico met the challenges of annual seasonality and periods of climate instability (Figure 12). Gone are the days when scholars and the public imagination envisioned ancient Maya theocratic ceremonial centres led by peaceful priest rulers, who looked more to the stars than to political engagement (Thompson 1966). More recently, the decipherment of Maya inscriptions and archaeological research aided by LiDAR mapping have revealed a tropical world with hundreds of cities, whose kings kept records of their successes in battles and other political machinations (Martin 2020). Cities, on average about 25 kilometres apart from each other, were surrounded by dispersed rural farmers who were drawn to cities for access to the massive artificial reservoirs during the five-month annual drought between February and late June. In fact, the entire Maya way of life has to be understood with regards to rainfall dependency, seasonality, and their reliance on water systems beginning about $400 \mathrm{BCE}$ 
(Scarborough 2003: 50-1; 2007). The Maya met these challenges relying on ingenuity, labour and stone tool technology since this area of the tropical world lacked beasts of burden, wheeled carts and metal tools.

The Maya lowlands is composed of limestone hills and ridges that are largely covered by deciduous hardwood forests and dispersed and variously sized pockets of fertile soils (Ford \& Nigh 2015). Further, topography, including entrenched rivers, and dispersed resources discouraged large-scale irrigation systems. Annual rainfall ranged from 135 to 370 centimetres, 90 per cent of which falls during the seven-month rainy season from late June through January (Scarborough 1993). While seasonal swamps or wetlands, 40-60 per cent of any given area (Dunning et al. 2006), flourish during the rainy season and become desiccated during the dry season, elsewhere much of the rain percolates through the porous limestone bedrock. Small- and large-scale water containment and conservation systems were vital during the annual dry season and agricultural downtime, especially for drinking water. In the rainy season, farmers were dispersed in their fields during the agricultural intensive period. Consequently, there was a degree of seasonal mobility - and power. Dispersed farmers lived in self-organising or heterarchical communities during the rainy season and became enfolded or nested into urban hierarchical systems during the dry season (Scarborough \& Lucero 2010).

The Global Climate Risk Index places Guatemala in the second highest tier, and Belize in its third highest (out of five; https://germanwatch.org/en/19777, accessed 13 June 2021). While not as high as Nepal (first tier), the risks are real in lowlying Central America, evidenced by climate refugees heading north to the US border. Global climate change and concomitant climate instability are a great risk to crops and water supply. In the past, the Maya dealt with extreme weather events, evidenced by long occupation histories - cities lasted over 1,000 years (c.300 BCE-900 CE). This success stands in stark contrast to today. For example, the October 2010 Hurricane Richard swept through central Belize with a vengeance. Yalbac Ranch properties, where Lucero works, was ground zero. The differential impact on ancient versus modern urban infrastructure was notable. We found minimal damage at the Classic Maya medium-sized city of Yalbac, which the Maya had abandoned by 900 CE. In contrast, modern infrastructure required replacement or repair-roads, buildings, bridges, ferries, and so on. In another, more extreme case, the Belize government ended up building a new capital, Belmopan, from scratch in 1970 in central Belize after they tired of rebuilding parts of Belize City along the coast of the Caribbean Sea after particularly harsh hurricane seasons. It is telling that archaeologists do not find any Maya settlement in areas hardest hit today by hurricanes and tropical storms. In nearly every circumstance, Maya materials and methods are more suitable for the humid semi-tropics, for example, pole and thatch versus cinder blocks and metal roofing. Pole and thatch houses are dark, damp and relatively cool, as is Classic Maya 


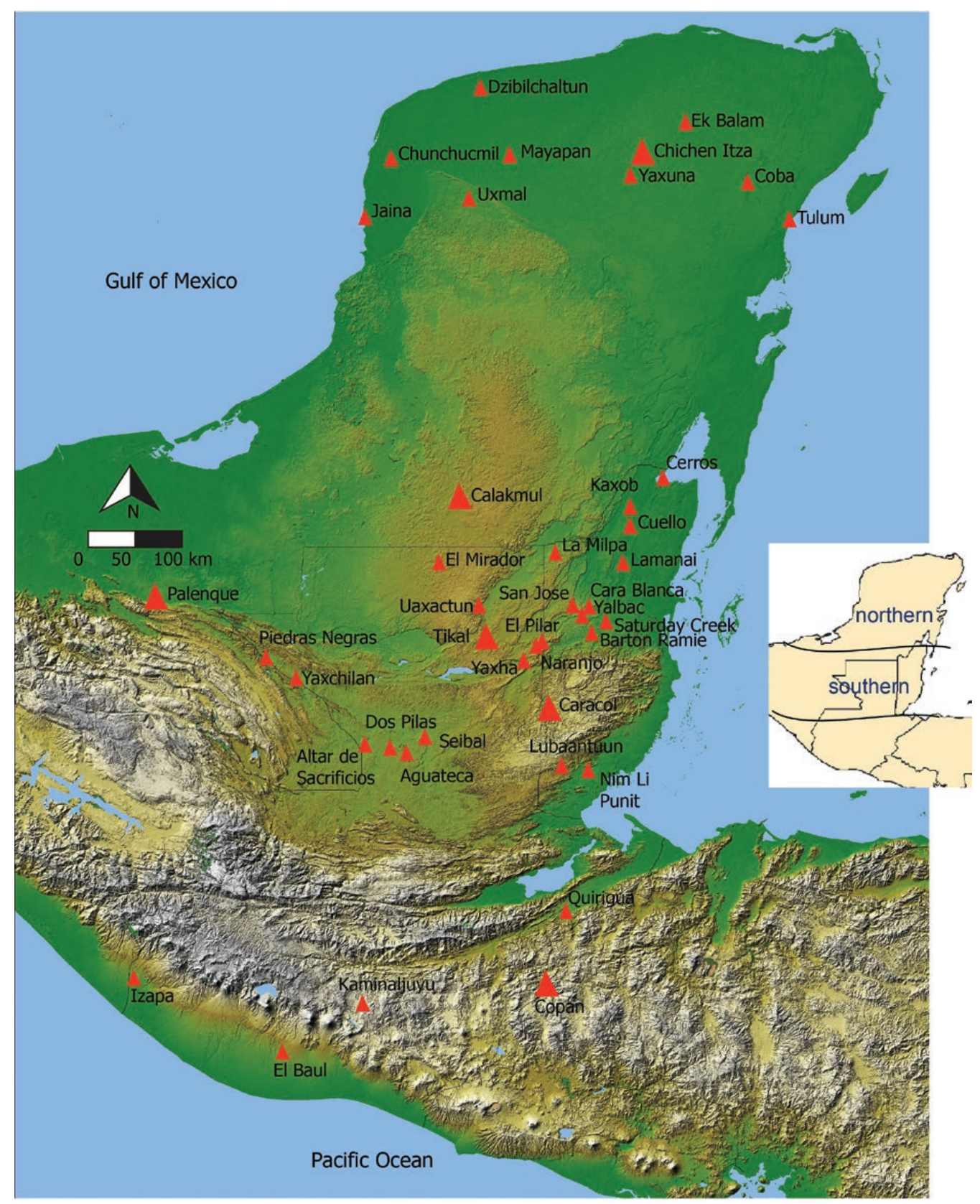

Figure 12. Map of the Maya area showing major cities. (Image: L.J. Lucero).

limestone monumental architecture. Maya traditional knowledge is astounding and relevant, but rarely considered in infrastructure and policy decisions.

Archaeologists have now recorded hundreds of Classic Maya cities, some that supported up to 80,000 people, if not more, and encompassed areas up to 200 square kilometres. Each had their own king supported by rural farmers (Lucero 2006). 
Some kings had more power than others, especially those at Tikal and Naranjo in Guatemala, Calakmul in Mexico and Caracol in Belize, none of which are located near lakes or rivers. Their low-density, dispersed agrarian urban system integrated water and agricultural systems, cities, farmsteads and communities, exchange networks, and resources (Lucero et al. 2015). The organic expansion of the largest cities revolved around water capture and storage to replenish reservoirs, crops and people (Scarborough 1993; 2003; 2007). The massive gravity-based reservoir system became increasingly larger and more sophisticated, incorporating dams, channels, filtration and so on (Scarborough et al. 2012). For example, causeways (sacbeob) also functioned as dams and walkways (Figure 13). Maintaining reservoir water quality would have been crucial to curtail the presence of water-borne parasites and diseases, such as hepatic schistosomiasis, and the build-up of noxious elements such as nitrogen (Burton et al. 1979). The Maya kept water clean by creating wetland biospheres using certain surface and sub-surface plants. Clean water is indicated by the presence of Nymphaea ampla, a species of water lily that can only flourish in still, clean waterand it also symbolises Maya kingship (Lucero et al. 2011).

Rural farmers depended on urban reservoirs during the dry season. In addition, cities exerted a centripetal pull on rural Maya through markets, public ceremonies and other large-scale public events (Lucero 2006). In turn, urban-based royals depended on the rural populace to fund the political economy in the form of labour, services such as craft specialists, hunters; agricultural produce such as maize, beans, manioc, squash, pineapple, tobacco, tomatoes; and forest resources, such as wood, fuel, construction materials, medicinal plants, chert, game, and fruit. Maya farmers planted non-contiguous plots to prevent the spread of pests and used diverse, localised, small-scale extensive and intensive subsistence technologies that included 'terraces, dams, canals and raised fields that were used to grow the staples of maize, beans and squash in house gardens, short-fallow infields, long-fallow outfields and combinations of these techniques' (Lucero 2017: 166). In addition to farming, the Maya promoted certain economically and culturally significant flora and fauna (Gómez-Pompa et al. 1987). Forest management strategies also likely included culling, land clearing, intentional fires for hunting and gathering wood for fuel, resource extraction including clay and chert for pottery and tool production, as well as limestone and wood for building materials (Ford \& Nigh 2015). The selective cultivation of species in orchards, home gardens, managed forests or tended fields in fallow allowed for cities and rural farmsteads to sustain themselves locally, sustainably (Fedick 2010; Ford \& Clarke 2016; Lentz et al. 2015). Forest management, in addition to the use of diverse agricultural strategies, encouraged subsistence flexibility and long-term, sustainable investment in the landscape.

The Maya relied on rainfall to nourish their fields and replenish reservoirs. Consequently, a series of prolonged droughts that struck between $c .800$ and $930 \mathrm{CE}$ 


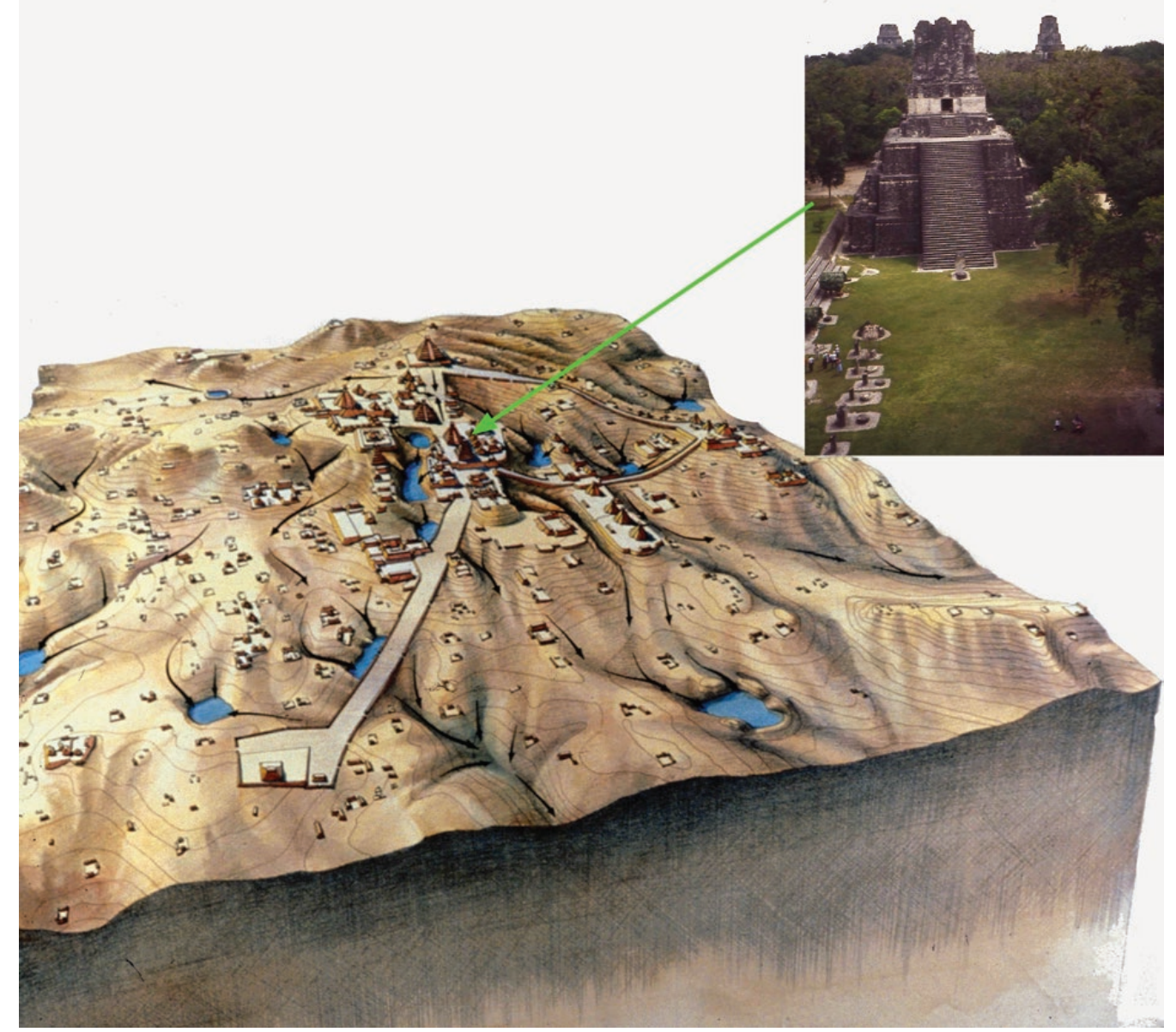

Figure 13. Rendition of Tikal, Guatemala, depicting causeways, reservoirs and open areas for gardens or even fields and orchards (Image: Vernon Scarborough) with view of Temple II (Image: L. J. Lucero).

(Douglas et al. 2015; Medina-Elizalde et al. 2010) had major repercussions (Lucero 2017). When reservoir levels dropped, water quality worsened and water lilies died, along with Maya kingship. Droughts led to crop failure and exacerbated any existing problems, including erosion, deforestation and overuse of resources. Kings had become dependent on the increasingly intricate, complex and interlinked water systems, setting the stage for their own downfall when the rains did not come, or came too late or too little (Lucero et al. 2015). The subsequent urban diaspora resulted in up to $c .90$ per cent (Turner \& Sabloff 2012) of farmers leaving the interior southern lowlands for coastal areas, major rivers, or larger lakes, such as the Belize River and Lake Petén Itzá, where market towns and trade thrived (Graham 2011; Masson \& Freidel 2012; Sabloff 2007). While this response was drastic, it was an adaptive strategy but one that worked as evidenced by the over seven million Maya currently living in Central America and beyond (McAnany \& Gallareta Negrón 2009). Abandoned 
cities were never re-occupied, which unfortunately makes looting, destruction, such as fill from monumental buildings used as road fill, and building over all the more easier.

Even when Maya population peaked c.600-800 CE in the Late Classic period, the Maya relied on diverse strategies to avoid depleting the resources upon which they relied - fertile soils, water, and diverse flora and fauna. In the past, the Maya URI supported more people than presently: current population density 'remains about one to two orders of magnitude less than the density' found in the Late Classic, indicating their long-term adaptation (Turner \& Sabloff 2012: 13912). Further, LiDAR mapping in northern Guatemala reveals an anthropogenic landscape interspersed with forests, leading archaeologists to estimate a population of 7-11 million in the central Maya lowlands in the Late Classic (Canuto et al. 2018). The Maya landscape was a mosaic of settlement, subsistence features and managed forests that supported a farming lifestyle for 4,000 years without massive deforestation, a fact that goes against current practices of clear-cutting and mono-cropping.

\section{Prospect}

As is clear from the three case studies presented, archaeologists have the unique ability to review the process of environmental change and resilience from much deeper and richer timescales, and have learned detailed lessons about societal and technological adaptation from the past. Indeed, as we have stressed, one of the most powerful lessons from the past is that the key to societal success lies in a community's ability to recognise the need to adapt and adjust their social and economic scaling and integration to meet longer-term trends (Weiss 2016: 62). There is, however, an equally significant lesson that communities, particularly those agglomerated into states, need to be aware that even successful adaptations can lead to irreversible path dependencies. In this context, we use path dependencies to refer to processes of 'how peopleand the institutions they create- become entangled (Hodder 2011) in situations from which they cannot easily extricate themselves ... The situations may involve relationships and social institutions as well as material circumstances, and the entanglements develop over time' (Hegmon et al. 2016: 173).

The case study of climate change, disaster risk and resilience in Nepal demonstrated a history of successful technical adaptation in Nepal to threats from disasters, both flooding and tectonic. In the former, analysis of settlement location within the Terai, and the urban morphology of Tilaurakot-Kapilavastu, demonstrated that communities selected fossil alluvial ridges to avoid annual inundations (Verardi 2007) and that larger settlements were able to concentrate greater resources in flood defences in the form of moats and ramparts (Davis et al. 2016). These adaptations lowered the risk to their inhabitants but still provided them with proximity to water for cultivation 
and transport. Many modern settlements established off these ridges have almost annually suffered from the anguish of flooding.

Although only 300 kilometres northeast as the crow flies, the Valley of Kathmandu faces a very different challenge in the form of intermittent high magnitude earthquakes. Long the focus of art historians and architects, little was known about their foundations or technological innovations, with a fairly consistent belief that most were less than 500 years old. The deployment of a unique interdisciplinary research team of archaeologists, geoarchaeologists, architects, structural engineers, geotechnical engineers, heritage professionals, artisans and a Sanskritist demonstrated that one of Kathmandu's most iconic monuments, the Kasthamandap, had successfully withstood regular earthquakes for over a millennium. Field and laboratory analysis of samples from its foundations and superstructure have demonstrated a highly advanced indigenous technology with evidence ranging from the use of 'engineered' soils and mortars to avoid liquafraction to the use of copper sheet around timber members in conservation interventions to both act as a waterproofing but also as a chemical retardant for both mould and termites (Coningham et al. 2019). Of course, the deep irony is that the details of this highly advanced structure could only be fully understood after its collapse in the 2015 Gorkha Earthquake, a collapse accelerated by poor modern conservation interventions in the 1970s and 1960s.

The uniqueness of the story of the Kasthamandap reinforces the challenges of understanding why some historic structures collapsed in Kathmandu and others did not. Moreover, the typical contemporary domination of 'educated professionals', such as architects and engineers with internationally recognised qualifications, over highly experienced skilled artisans further accentuates this situation. This is played out in parallel with the preference of modern materials with internationally recognised standards, such as those benchmarked by the International Standards Organisation, over vernacular and indigenous materials - creating two separate worlds. The current gaps between the two are not being investigated, as donor agencies do not fund 'research' and research agencies are not frequently tempted to fund applied research, particularly with the recent cutting of GCRF funding in the UK. As a result, we do not actually know how many individuals were killed in the 2015 earthquake by vernacular buildings rather than those constructed in modern materials. Similarly, we do not know how many of those vernacular structures which did collapse had had modern materials assimilated, creating hybrids, which as our team engineers identified, mixed materials which perform in very different ways and mixed rigidity with flexibility ending often in disaster. The dangers of hybridisation are also found in the trans-Himalayan walled city of Lo Manthang, where increasing rainfall has been met by some residents with the deployment of plastic sheeting over their mud roofs. While keeping rain off the mud treatment, the plastic encourages the build up of moisture where the two join, leading to the rotting of the timber supports and the collapse of 
the ceilings and walls. Again, as in the case of Kathmandu, reference to traditional artisans offers a way of preserving these unique structures despite the environmental changes by referencing indigenous knowledge based on millennia of experimentation and adaptation.

Our second case study, disaster risk, adaptation and resilience in Medieval Sri Lanka, offered a very clear example of the development and employment of mega-infrastructure to lessen the risk of drought as the state at Anuradhapura developed and expanded. Its success is striking as it allowed an urban agglomeration of perhaps 200,000 people in the northern Dry Zone of the island. This significance is underpinned by the facts that the areas's natural carrying capacity is only 0.4 people per square kilometre and the modern city had a population of less than 70,000 in 2012 (Department of Census and Statistics 2012). While historians and archaeologists have tended to be overwhelmed by the integrated system of vast reservoirs and canals, the parallel rural system of simple gravity-fed cascade tanks have been less intensely studied - perhaps drawn to what Edmund Leach termed the 'propaganda myth' of kingship and its associated mega-works (1959: 15). Similarly, scholars have been drawn to the architecture of the monastic complexes which surrounded the city, rather than the network of rural communities which generated the surplus which supported them. This diversity of systems appears to have allowed farming communities to have survived the collapse of the mega-infrastructure as climatic instability, combined with societal adjustments with access to labour, forced a path dependency which could only conclude with an almost entire 'systems collapse'. In this case, the parallelism allowed the farming communities to relocate to more favourable environments, both in terms of climate and social contexts. The continued favouring of mega-infrastructure by both donors and governments risks the creation of similar pathway dependency, where the interdependencies are so entangled that adaptation becomes irreversible and bigger is certainly not better.

Clearly, parallel lessons also come from our final case study, disaster risk, resilience and the Classic Maya. The tracing of urban-rural interaction and adaptation to the seasonal availability of water in another part of the tropics, traced echoes of Sri Lanka's 'Hydraulic Civilization' with a landscape of dispersed farmers. Indeed, recent research with LiDAR has demonstrated that the Maya landscape was a mosaic of settlement, subsistence features and managed forests that supported a farming lifestyle for 4,000 years without massive deforestation, a fact that goes against current practices of clear-cutting and mono-cropping. Self-organised, or heterarchical, during the rainy season, they were enfolded or nested into urban hierarchical systems during the dry season (Scarborough \& Lucero 2010). Their choice of localities, evidenced by deep occupation histories, demonstrated the awareness of disaster risk and its mitigation; a lesson only too clear when compared with the widespread devastation caused amongst new settlements during extreme weather, such as Hurricane Richard 
in 2010. The outcome of centuries of experimentation, Maya vernacular architecture demonstrates successful adaptation to its environment in stark contrast to the increasingly ubiquitously favoured cinder block and metal sheet roofing. As noted above, Maya traditional knowledge is astounding and relevant, but rarely considered in infrastructure and policy decisions. Their indigenous knowledge of both water and forest management underpinned the development of state level societies, despite the lack of metal, beasts of burden and wheeled carts. However, the massive urban gravity-based reservoir systems which supported those cities became increasingly larger and more sophisticated, incorporating dams, channels and filtration (Scarborough et al. 2012). These path-dependent practices were successful adaptations during a relatively stable climate but were unable to mitigate the series of prolonged droughts that struck between c.800 and 930 CE (Douglas et al. 2015; Medina-Elizalde et al. 2010). Crop failure, erosion, deforestation and the over-investment of dwindling resources in increasingly intricate, complex and interlinked water systems resulted in the dispersal of urban communities (Lucero et al. 2015), and a process which Yoffee refers to as 'ruralisation' (2005: 60).

Archaeologists generate evidence to identify lessons from the past. However, they can, and should also, be proactive in disseminating their relevant research beyond academic publications to engage with people, communities and policy makers. To take a step in this direction, the American Anthropological Association created the Climate Change Task Force (2010-2014) to address the role of anthropology in dealing with climate change from a human perspective rather than a political and economic topdown one - adaptation, resilience and vulnerability. The task force, on which Lucero served, included archaeologists, cultural anthropologists and biological anthropologists. We met several times between 2012 and 2014 at conferences and seminars, supported by the School for Advanced Research (Santa Fe, New Mexico), the Atlantic Philanthropies (New York City) and the American Anthropological Association. The resulting report, available for free online (see Fiske et al. 2015), lays out step by step not only the usual topics when discussing the impacts of climate change, such as the causes of $\mathrm{CO}_{2}$ emissions and mitigation, but those taken at the community level. We also generated a Statement on Humanity and Climate Change that lists the eight key intersections of climate change and anthropology-including one devoted to archaeology (see also Cox 2014; Turner et al. 2016):

The archaeological record reveals diverse human adaptations and innovations to climate stresses occurring over millennia, providing evidence that is relevant to contemporary human experience. The archaeological record shows that diversity and flexibility increase resilience to stress in complex adaptive systems, and that successful adaptations incorporate principles of sustainability.

Future disasters are a given, especially in view of global climate change. Risks can be mitigated if we look to our past for lessons, because it embodies practices, challenges, 
strategies, successes and failures from which to devise sustainable solutions (Fiske et al. 2015; Isendahl et al. 2018; Lucero \& Gonzalez Cruz 2020). For example, in an article comparing ancient Anuradhapura, Angkor, and Tikal (with Roland Fletcher), we concluded with this lesson, that: 'In the end, the different histories of kings and farmers relate to the different constructs in which they existed: inflexible vs flexible strategies; a reliance on massive $v s$ small-scale diverse water systems; and entrenched and rigid $v$ s resilient and adaptable systems' (Lucero et al. 2015: 1151). Thus, it is not only vital to save our cultural heritage and that of others for the sake of history and tourism, but for lessons from which we can all benefit. While we have discussed here three semi-tropical societies, the points we make are relevant for all tropical regionsand future urban planning globally. We have presented cases of successful and unsuccessful adaptations in urban settings from the tropical past to provide instances of how archaeology and archaeologists can also play a greater role in future urban planning.

Having shed doubt on the success of some mega-infrastructure irrigation projects in the tropics, we also need to acknowledge that there are dangers associated with the development of modern urban mega-infrastructure on historic urban infrastructure. This is exemplified by Lahore's Orange Line, part of the China Pakistan Economic Corridor initiative, whose 27.12 kilometre line was built at a cost of US\$1626 million (CPEC 2021). Its path along the line of the historic Grand Trunk Road, however, impacted 12 protected Medieval and Colonial monuments and buildings, including within 28 metres of the 17th century Mughal Shalimar Gardens UNESCO World Heritage Site (Coningham \& Lewer 2019: 154) (Figure 14). We could write a book on similar examples of our past being erased globally, and with it knowledge of sustainable urban planning and indigenous practice and knowledge.

To conclude, as we noted earlier, the ancient Indian scripture Yajurveda states the importance of taking care of Mother Earth so that she can take care of us. Future discussions of urban infrastructure must keep this in mind, so we, too, can live in cities for millennia. Combining knowledge acquired by interdisciplinary teams from the archaeological record with indigenous knowledge are powerful tools for future sustainable urban planning. Our case studies leave little doubt of this fact. In brief, the purpose of this work is to illustrate that to save ourselves (and Earth), we must also save our past.

\section{Acknowledgements}

Our post-disaster research and fieldwork across the Kathmandu Valley would not have been possible without the hard work and dedication of team members from the Department of Archaeology (Government of Nepal), ICOMOS (Nepal), Tribhuvan University, Durham University, Newcastle University, the University of Stirling and 


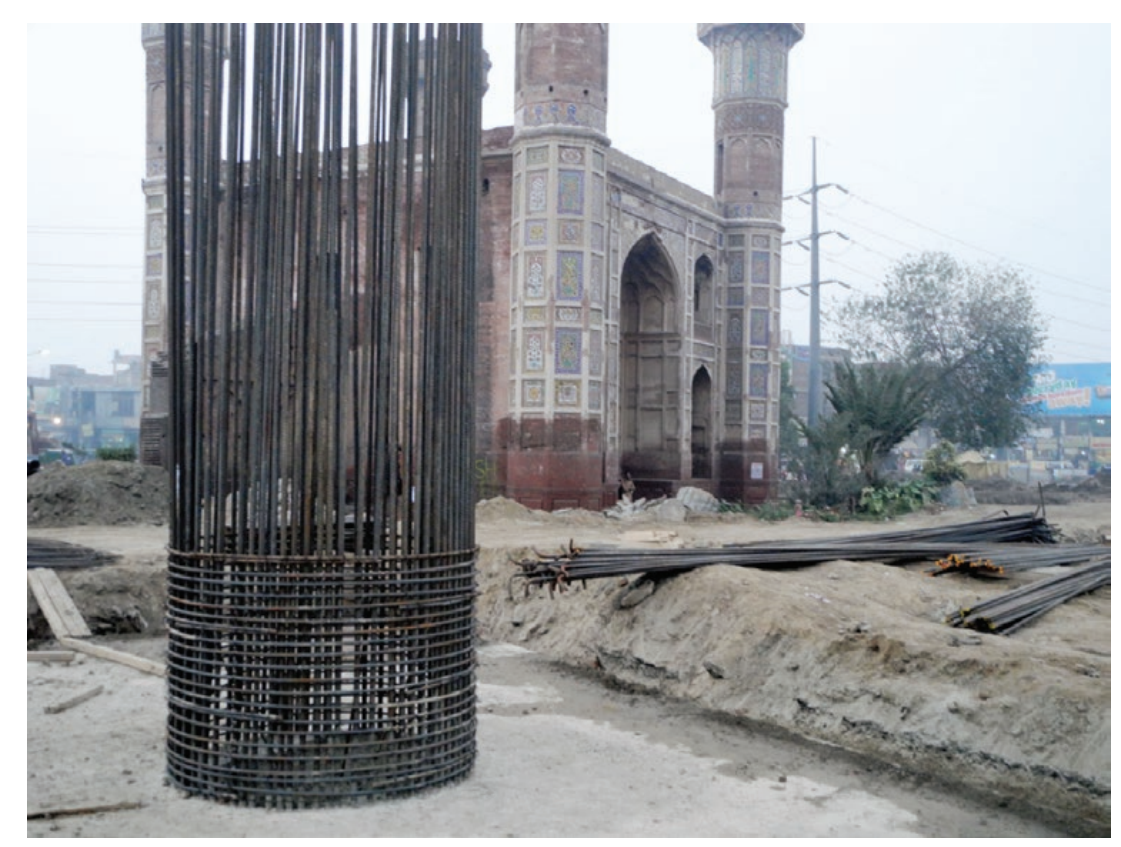

Figure 14. View of the Orange Line's viaduct foundation beside the Chauburji Gateway in Lahore, Pakistan. (Image: Durham UNESCO Chair).

University of Bradford, and other partners. The British Academy's Global Challenges Research Fund's Project 'Reducing Disaster Risk to Life and Livelihoods by Evaluating the Seismic Safety of Kathmandu's Historic Urban Infrastructure' (CI170241) sponsored the fieldwork, as well as the co-design and installation of the Dhukuti museum display with additional financial support from UNESCO (Kathmandu), the Alliance de Protection du Patrimoine Culturel Asiatique, the Pashupati Area Development Trust and Durham University's Institute of Medieval and Early Modern Studies (IMEMS), now hosted by the Hanuman Dhoka Museum Development Committee (Department of Archaeology, Government of Nepal). We are very grateful to the Austrian Academy of Sciences for their partnership and Vienna-based symposium, and to the National Museum in Kathmandu for hosting our final dissemination workshop. Finally, we would like to acknowledge the support and passion shown by Mr Rajesh Shakya and the other members of the Kasthamandap Reconstruction Committee, the master craftsmen and the ward members who are rebuilding the Kasathamandap. We also acknowledge the contributions of the following colleagues to our broader discussions: Roland Fletcher, Kosh Prasad Acharya, Ian Simpson, Kai Weise, Prishanta Gunawardhana, Shahnaj Husne Jahan, K. Krishnan, Mark Manuel, Christopher Davis and Keir Strickland.

Lucero's projects in central Belize have been funded over the years by the National Science Foundation, most recently (BCS 2020465) to fund a rescue archaeology programme, which is gratefully acknowledged. Other funding was provided by the 
University of Illinois Research Board and landowners Forestland Group, which is also much appreciated. Research in Belize would not have been possible without permission and support from the Belize Institute of Archaeology of the National Institute of Culture and History — many thanks go to the Director, Dr John Morris. In Belize, logistical support and friendship provided by Jeff Roberson of Yalbac Ranch is invaluable. We could not have conducted field work without our top-notch field crew_-foremen Cleofo Choc, Stanley Choc and José Ernesto Vasquez, field assistants, and undergraduate and graduate students.

Notes on the authors: The Project 'Reducing Disaster Risk to Life and Livelihoods by Evaluating the Seismic Safety of Kathmandu's Historic Urban Infrastructure', funded through the British Academy's GCRF Cities and Infrastructure Programme (CI170241), brought together an international and interdisciplinary team of academics, heritage practitioners, as well as local and national government and non-governmental organisations to co-develop and pilot methodologies for historic urban infrastructure in Kathmandu.

The Principal Investigator, Robin Coningham, holds UNESCO's 2014 Chair in Archaeological Ethics and Practice in Cultural Heritage at Durham University, and is committed to the protection of cultural heritage, joining over 30 international missions for UNESCO. He has co-directed UNESCO's archaeological fieldwork within the Greater Lumbini Area of Nepal since 2011 and was invited to co-direct post-disaster excavations in Kathmandu with Kosh Prasad Acharya and Ram Bahadur Kunwar after the 2015 Gorkha Earthquake by UNESCO and the Government of Nepal. His publications include the 2012 Appropriating the Past: Philosophical Perspectives on the Practice of Archaeology and the 2015 Archaeology of South Asia with Cambridge University Press, and Pivot Palgrave's Archaeology, Heritage Protection and Community Engagement in South Asia in 2019.

Lisa J. Lucero (PhD, UCLA, 1994) is a Fellow of the American Association for the Advancement of Science and a Professor of Anthropology at the University of Illinois at Urbana-Champaign. Her interests focus on the emergence and demise of political power, ritual, water management, the impact of climate change on society, sustainability tropical regions and the Classic Maya. She has been conducting archaeology projects in Belize for 30 years. Dr Lucero uses insights from the Maya on tropical sustainability issues, working with colleagues working in Southeast Asia. Currently, she is compiling non-anthropocentric insights from her research on the ancient Maya and working with the living Maya that are relevant for today's sustainability planning.

\section{References}

Banerjee, N.R. (1965), The Iron Age of India (New Delhi, Munshiram Manoharlal).

Bebermeier, W., Meister, J., Withanachchi, C.R., Ingo Middelhaufe, I. \& Schutt, B. (2017), 'Tank Cascade Systems as a Sustainable Measure of Watershed Management in South Asia', Water, 9(231). doi: $10.3390 /$ w9030231

Bell, H.C.P. (1904), Archaeological Survey of Ceylon, Annual Report 1892 (Colombo, Ceylon Government Press).

Burton, T.M., King, D.L., Ball, R.C. \& Baker, T.G. (1979), Utilization of Natural Ecosystems for Waste Water Renovation (Chicago, United States Environmental Protection Agency).

Canuto, M.A., Estrada-Belli, F., Garrison, T.G., Houston, S.D., Acuña, M.J., Kováč, M., Marken, D., Nondédéo, P., Auld-Thomas, L., Castanet, C., Chatelain, D., Chiriboga, C.R., Drápela, T., 
Lieskovský, T., Tokovinine, A., Velasquez, A., Fernández-Díaz, J.C. \& Shrestha, R. (2018), 'Ancient Lowland Maya Complexity as Revealed by Airborne Laser Scanning of Northern Guatemala', Science, 361: eaau0137.

Chakrabarti, D.K. (1976), 'India and the Druids', Antiquity, 50(197): 66-7.

Chakrabarti, D.K. (2000), 'Colonial Indology and Identity', Antiquity, 74(285): 667-71.

Codrington, H.W. (1960), 'The Decline of the Medieval Sinhalese Kingdom', Journal of the Royal Asiatic Society (Ceylon Branch), 7: 93-103.

Coningham, R.A.E. (1995), 'Dark Age or Continnum? An Archaeological Analysis of the Second Emergence of Urbanism in South Asia', in F.R. Allchin (ed.), The Archaeology of Early Historic

South Asia: The Emergence of Cities and States (Cambridge, Cambridge University Press), 54-72.

Coningham, R.A.E. (1999), Anuradhapura: The British-Sri Lankan Excavations at Anuradhapura Salgaha

Watta 2. Volume 1: The Site (Oxford, Archaeopress).

Coningham, R.A.E. (2006), Anuradhapura: The British-Sri Lankan Excavations at Anuradhapura Salgaha Watta 2. Volume 2: The Artefacts (Oxford, Archaeopress).

Coningham, R.A.E. \& Gunawardhana, P. (2013), Anuradhapura, Volume 3: The Hinterland (Oxford, Archaeopress).

Coningham, R.A.E. \& Lewer, N. (2019), 'Communities, Identities, Conflict and Appropriation in South Asia', in R.A.E. Coningham \& N. Lewer (eds), Archaeology, Cultural Heritage Protection and Community Engagement in South Asia (Singapore, Palgrave Macmillan), 151-64.

Coningham, R.A.E. \& Manuel, M.J. (2009), 'The Early Empires of South Asia', in T. Harrison (ed.), The Great Empires of the Ancient World (London: Thames \& Hudson), 226-49.

Coningham, R.A.E. \& Young, R.L. (2015), The Archaeology of South Asia: From the Indus to Asoka (Cambridge, Cambridge University Press).

Coningham, R.A.E., Acharya, K.P., Davis, C.E., Weise, K., Kunwar, R.B. and Simpson, I. (2018), 'Look Down, Not Up: Protecting the Post-Disaster Sub-Surface Heritage of the Kathmandu Valley's UNESCO World Heritage Site', in L. Bracken, H.A. Ruszczyk and T. Robinson (eds), Evolving Narratives of Hazard and Risk: The Gorkha Earthquake, Nepal, 2015 (Cham, Palgrave), 159-81.

Coningham, R.A.E., Gunawardhana, P., Davis, C.E., Adikari, G., Simpson, I.A., Strickland, K.M, Gilliland, K. \& Manuel, M.J. (2012), 'Contextualising the Tabbova-Maradanmaduva "Culture": Excavations at Nikawewa, Tirappane, Anuradhapura District, Sri Lanka', South Asian Studies, 28(1): 1-14.

Coningham, R.A.E., Acharya, K.P., Simpson, I.A., Davis, C.E., Kunwar, R.B., Weise, K., Joshi, A., Kinnaird, K. \& Nina Mirnig, N. (2021), The Kasthamandap and its Archaeological and Geoarchaeological Sequence (Kathmandu, Kasthamandap Reconstruction Committee).

Coningham, R.A.E., Gunawardhana, P., Manuel, M.J., Adikari, G., Katugampola, M., Young, R.L., Schmidt, A., Krishnan, K., Simpson, I., McDonnell, G. \& Batt, C. (2007), 'The State of Theocracy: Defining an Early Medieval Hinterland in Sri Lanka', Antiquity, 81(313): 699-719.

Coningham, R.A.E., Acharya, K.P., Barclay, C.P., Barclay, R., Davis, C.E., Graham, C., Hughes, P.N., Joshi, A., Kelly, L., Khanal, S., Kilic, A., Kinnaird, T., Kunwar, R.B., Kumar, A., Maskey, P.N., Lafortune-Bernard, A., Lewer, N., McCaughie, D., Mirnig, N., Roberts, A., Sarhosis, V., Schmidt, A., Simpson, I.A., Sparrow, T., Toll, D.G., Tully, B., Weise, K., Wilkinson, S. \& Wilson, A. (2019), 'Reducing Disaster Risk to Life and Livelihoods by Evaluating the Seismic Safety of Kathmandu's Historic Urban Infrastructure: Enabling an Interdisciplinary Pilot', Journal of the British Academy, 7(2): 45-82.

Cox, M. (2014), 'Modern Disturbances to a Long-Lasting Community-Based Resource-Management System: The Taos Valley Acequias', Global Environmental Change, 24: 213-22.

CPEC (2021), Orange Line, Lahore (Islamabad, CPEC). http://cpec.gov.pk/project-details/46

CRED (2017), Natural Disasters 2017 (Louven, Centre for Research on the Epidemiology of Disasters). https://reliefweb.int/sites/reliefweb.int/files/resources/adsr_2017.pdf 
Crumley, C.L. (1979), 'Three Locational Models: An Epistemological Assessment for Anthropology and Archaeology', in M.B. Schiffer (ed.), Advances in Archaeological Method and Theory (New York, Academic Press), 141-73.

Culavamsa (1927) (London, Pali Text Society).

Dales, G.F. (1966), 'The Decline of the Harappans', Scientific American, 214(5): 92-101.

Davis, C.E. \& Coningham, R.A.E. (2018), 'Pilgrimage and Procession: Temporary Gatherings and Journeys Between the Tangible and Intangible Through the Archaeology of South Asia', World Archaeology, 50(2): 347-63.

Davis, C.E., Coningham, R.A.E., Gunawardhana, P. \& Manuel, M.J. (2013), 'Epigraphy in the Hinterland', in R.A.E. Coningham \& P. Gunawardhana (eds), Anuradhapura Volume 3: The Hinterland (Oxford, Archaeopress), 445-58.

Davis, C.E., Coningham, R.A.E., Acharya, K.P., Simpson, I.A., Tremblay, J., Kunwar, R.B., Manuel, M.J., Krishna Bahadur, K.C. \& Bidari, B. (2016), 'Re-investigating Tilaurakot's Ancient Fortifications: A Preliminary Report of Excavations Through the Northern Rampart (Nepal)', Ancient Nepal, 190: 30-46.

Davis, C.E., Coningham, R.A.E., Acharya, K.P., Kunwar, R.B., Forlin, P., Weise, K., Maskey, P.N., Joshi, A., Simpson, I.A., Toll, D., Wilkinson, S., Hughes, P., Sarhosis, V., Kumar, A. and Schmidt, A. (2020), 'Identifying Archaeological Evidence of Past Earthquakes in a Contemporary Disaster Scenario: Case-Studies of Damage, Resilience and Risk Reduction from the 2015 Gorkha Earthquake and Past Seismic Events within the Kathmandu Valley UNESCO World Heritage Property (Nepal)', Journal of Seismology, 24(4): 729-51.

Diamond, J. (2004), Collapse: How Societies Choose to Fail or Succeed (New York, Viking).

Dias, M. (2001), The Growth of Buddhist Monastic Institutions in Sri Lanka from Brāhmī Inscriptions (Colombo, Department of Archaeological Survey).

Douglas, P.M.J., Pagani, M., Canuto, M.A., Brenner, M., Hodell, D.A., Eglinton, T.I. \& Curtis, J.H. (2015), 'Drought, Agricultural Adaptation, and Sociopolitical Collapse in the Maya Lowlands', Proceedings of the National Academy of Sciences, 112: 5607-12.

Department of Census and Statistics (2012), Census of Population and Housing (Colombo, Ministry of Finance and Planning, Government of Sri Lanka after Ministry of Finance and Planning).

Dunning, N.P., Beach, T. \& Luzzadder-Beach, S. (2006), 'Prehispanic Agrosystems and Adaptive Regions in the Maya Lowlands', in L.J. Lucero \& B.W. Fash (eds), Precolumbian Water Management: Ideology, Ritual, and Politics (Tucson, University of Arizona Press), 81-91.

Dutta, S.K. (1909), The Desire of India (London, Church Missionary Society).

Fedick, S.L. (2010), 'The Maya Forest: Destroyed or Cultivated by the Ancient Maya?, Proceedings of the National Academy of Sciences, 107: 953-54.

Fiske, S., Crate, S., Crumley, C., Galvin, K., Lazarus, H., Luber, G., Lucero, L.J., Oliver-Smith, A., Orlove, B., Strauss, S. \& Wilk, R. (2015), Changing the Atmosphere: Anthropology and Climate Change, American Anthropological Association Climate Change Task Force Report (Arlington, VA, American Anthropological Association). https://s3.amazonaws.com/rdcms-aaa/files/production/ public/FileDownloads/pdfs/cmtes/commissions/upload/GCCTF-Changing-the-Atmosphere.pdf

Ford, A. \& Clarke, K.C. (2016), 'Linking the Past and Present of the Ancient Maya: Lowland Land Use, Population Distribution, and Density in the Late Classic Period', in C. Isendahl \& D. Stump (eds), Oxford Handbook of Historical Ecology and Applied Archaeology (Oxford, Oxford University Press). doi: 10.1093/oxfordhb/9780199672691.013.33.

Ford, A. \& Nigh, R. (2015), The Maya Forest Garden: Eight Millennia of Sustainable Cultivation of the Tropical Woodlands (Walnut Creek, Left Coast Press).

Gautam, D., Pradhananga, S., Kunwar, R.B. \& Sharma, M.K. (2015), Preliminary Report of Monuments Affected by Earthquake April 252015 (Kathmandu, Department of Archaeology).

Gilliland, K., Simpson, I.A., Adderley, W.P., Burbidge, C., Cresswell, A., Sanderson, D., Coningham, R., Manuel, M., Strickland, K., Gunawardhana, P. \& Adikari, G. (2013), 'The Dry Tank: Development 
and Disuse of Water Management Infrastructure in the Anurādhapura Hinterland, Sri Lanka', Journal of Archaeological Sciences, 40: 1012-28.

Gómez-Pompa, A., Salvaor Flores, E. \& Sosa, V. (1987), 'The "Pet Kot": A Man-Made Tropical Forest of the Maya', Interciencia, 12: 10-15.

Gordon, D.H. (1960), The Prehistoric Background of Indian Culture (Bombay, N.M. Tripathi).

Government of India (Ministry of External Affairs) (2007), Declaration of the Fourteenth SAARC Summit. www.mea.gov.in/press-releases.htm?dt1/2378/ Declaration+of+the+Fourteenth+SAARC+Summit

Government of India (Prime Minister's Office) (2021), Prime Minister's Address at Climate Adaptation Summit 2021. https://pib.gov.in/PressReleaseIframePage.aspx?PRID=1692331

Graham, E. (2011), Maya Christians and their Churches in Sixteenth-century Belize (Gainesville, University Press of Florida).

Gunawardana, R.A.L.H. (1979), Robe and Plough: Monastic and Economic Interest in Early Medieval Sri Lanka (Tucson, University of Arizona Press).

Harding, S. \& Penny, A. (eds) (2020), State of the Tropics 2020 Report (Douglas, Australia, James Cook University).

Hegmon, M., Howard, J.B., O’Hara, M. \& Peeples, M.A. (2016), 'Path Dependence and the Long-term Trajectory of Prehistoric Hohokam Irrigation in Arizona', in L. Der \& F. Fernandini (eds), Archaeology of Entanglement (London, Routledge), 173-88.

Hodder, I. (2011), 'Human-Thing Entanglement: Towards an Integrated Archaeological Perspective', Journal of the Royal Anthropological Institute, 17(1): 154-77.

Isendahl, C., Lucero, L.J. \& Heckbert, S. (2018), 'Sustaining Freshwater Security and Community Wealth: Diversity and Change in the Pre-Columbian Maya Lowlands', in F. Sulas \& I. Pikiray (eds), Water and Society: Resilience, Decline, and Revival from Ancient Times to the Present (London, Routledge), 17-39.

Jones, W. (1798), 'The Third Anniversary Discourse, Delivered 2d February, 1786: On the Hindus', Asiatick Researches, 1: 415-31.

Jung, S.J.A., Davies, G., Ganssen, G. \& Kroon, D. (2004), 'Stepwise Holocene Aridification in NE-Africa Deduced from Dust Borne Radiogenic Isotope Records', Earth and Planetary Science Letters, 221: 27-37.

Kosambi, D.D. (1965), The Culture and Civilization of Ancient India in Historical Outline (London, Routledge \& Kegan Paul).

Lambrick, H.T. (1967), 'The Indus Flood-Plain and the Indus Civilization', The Geographical Journal, 133(4): 483-95.

Lansing, J.S. (1991), Priests and Programmers: Technologies of Power in the Engineered Landscape of Bali (Princeton, University of Princeton).

Leach, E.R. (1959), 'Hydraulic Society in Ceylon', Past \& Present, 15(1): 2-16

Lentz, D., Magee, K., Weaver, E., Jones, J., Tankersley, K., Hood, A. \& Dunning, N. (2015), 'Agroforestry and Agricultural Practices of the Ancient Maya at Tikal', in D. Lentz, N. Dunning \& V. Scarborough (eds), Tikal: Paleoecology of an Ancient Maya City (Cambridge, Cambridge University Press), 152-85.

Lucero, L.J. (2006), Water and Ritual: The Rise and Fall of Classic Maya Rulers (Austin, University of Texas Press).

Lucero, L.J. (2017), 'Ancient Maya Water Management, Droughts, and Urban Diaspora: Implications for the Present', in N. Sanz, R.C. Lewis, J. Pulido Mata \& C. Connaughton (eds), Tropical Forest Conservation: Long-Term Processes of Human Evolution, Cultural Adaptations and Consumption Patterns (UNESCO Mexico), 162-88.

Lucero, L.J. \& Gonzalez Cruz, J. (2020), 'Reconceptualizing Urbanism: Insights from Maya Cosmology', Frontiers in Sustainable Cities: Urban Resource Management, 2: 1. doi: 10.3389/frsc.2020.00001 
Lucero, L.J., Fletcher, R. \& Coningham, R. (2015), "From "Collapse" to Urban Diaspora: The Transformation of Low-Density, Dispersed Agrarian Urbanism', Antiquity, 89: 1139-54.

Lucero, L.J., Gunn, J.D. \& Scarborough, V.L. (2011), 'Climate Change and Classic Maya Water Management', Water, 3: 479-94.

Madella, M. \& Fuller, D.Q. (2006), 'Palaeoecology and the Harappan Civilisation of South Asia: A Reconsideration', Quaternary Science Reviews, 25: 1283-301.

Marshall, J.H. (1951), Taxila: An Illustrated Account of Archaeological Excavations (Cambridge, Cambridge University Press).

Marshall, J.H. (1960), A Guide to Taxila (Cambridge, Cambridge University Press).

Martin, S. (2020), Ancient Maya Politics: A Political Anthropology of the Classic Period 150-900 CE (Cambridge, University of Cambridge Press).

Masson, M.A. \& Freidel, D.A. (2012), 'An Argument for Classic Era Maya Market Exchange', Journal of Anthropological Archaeology, 31: 455-84.

McAnany, P.A. \& Gallareta Negrón, T. (2009), 'Bellicose Rulers and Climatological Peril?: Retrofitting Twenty-First-Century Woes on Eight-Century Maya Society', in A. McAnany \& N. Yoffee (eds), Questioning Collapse: Human Resilience, Ecological Vulnerability, and the Aftermath of Empire (Cambridge, Cambridge University Press), 142-75.

Medina-Elizalde, M., Burns, S.J., Lea, D.W., Asmerom, Y., von Gunten, L., Polyak, V., Vuille, M. \& Karmalkar, A. (2010), 'High Resolution Stalagmite Climate Record from the Yucatán Peninsula Spanning the Maya Terminal Classic Period', Earth and Planetary Science Letters, 298: 255-62.

Middleton, G.D. (2017), Understanding Collapse: Ancient History and Modern Myths (Cambridge, Cambridge University Press).

NAO (1992), Overseas Aid: Water and the Environment (London, HMSO). www.nao.org.uk/pubsarchive/ wp-content/uploads/sites/14/2018/11/Overseas-Aid-Water-and-the-Environment.pdf

Nigam, R., Dubey, R. \& Saraswat, R. (2016), 'Ancient Indians (Harappan Settlement) Were Aware of Tsunami/Storm Protection Measures: A New Interpretation of Thick Walls at Dholavira, Gujarat', Current Science, 111(12): 2040-3.

OECD (2003), Development and Climate Change in Bangladesh: Focus on Coastal Flooding and the Sundarbans (Paris, OECD). www.oecd.org/env/cc/21055658.pdf

Pieris, P.E. (1925), 'Nagadipa and Buddhist Remains in Jaffna', Journal of the Royal Asiatic Society (Ceylon Branch), 28: 40-67.

Ramaswamy, S. (2000), 'History at Land's End: Lemuria in Tamil Spatial Fables', Journal of Asian Studies, 59(3): 575-602.

Rao, S.R. (1973), Lothal and the Indus Civilization (Bombay, Asia Publishing House).

Richon, M. (2019), 'Protecting Heritage and Strengthening Community Engagement in Nepal', in R.A.E. Coningham \& N. Lewer (eds), Archaeology, Cultural Heritage Protection and Community Engagement in South Asia (Singapore, Palgrave Macmillan), 75-88.

Sabloff, J.A. (2007), 'It Depends on How you Look at Things: New Perspectives on the Postclassic Period in the Northern Maya Lowlands', Proceedings of the American Philosophical Society, 151: 11-25.

Scarborough, V.L. (1993), 'Water Management in the Southern Maya Lowlands: An Accretive Model for the Engineered Landscape', Research in Economic Anthropology, 7: 17-69.

Scarborough, V.L. (2003), The Flow of Power: Ancient Water Systems and Landscapes (Santa Fe, School of American Research Press).

Scarborough, V.L. (2007), 'Colonizing a Landscape: Water and Wetlands in Ancient Mesoamerica', in V.L. Scarborough \& J. Clark (eds), The Political Economy of Ancient Mesoamerica: Transformations during the Formative and Classic Periods (Albuquerque, University of New Mexico Press), 163-74.

Scarborough, V.L. \& Burnside, W.R. (2010), 'Complexity and Sustainability: Perspectives from the Ancient Maya and the Modern Balinese'. American Antiquity, 75: 327-63. 
Scarborough, V.L. \& Lucero, L.J. (2010), 'The Non-Hierarchical Development of Complexity in the Semitropics: Water and Cooperation', Water History, 2: 185-205.

Scarborough, V.L., Dunning, N.P., Tankersley, K.B., Carr, C., Weaver, E., Grizioso, L., Lane, B., Jones, J.G., Buttles, P., Valdez, F. \& Lentz, D.L. (2012), 'Water and Sustainable Land Use at the Ancient Tropical City of Tikal, Guatemala', Proceedings of the National Academy of Sciences, 109: 12408-13.

Selter, E. (2007), Upper Mustang: Cultural Heritage of Lo Tso Dhun (Kathmandu, UNESCO).

Seneviratna, A. (1994), Ancient Anuradhapura (Colombo, Archaeological Survey Department).

Slusser, M.S. (1982), Nepal Mandala: A Cultural Study of the Kathmandu Valley (Princeton, Princeton University Press).

Slusser, M.S. and Vajracharya, G. (1974), 'Two Medieval Nepalese Buildings: An Architectural and Cultural Study', Artibus Asiae, 36(3): 169-218.

Srisangeerthanan, S., Lewangamage, C. \& Wickramasuriya, S. (2015), 'Tropical Cyclone Damages in Sri Lanka', Wind Engineers, JAWE, 40(3): 294-302.

Strickland, K.M., Coningham, R.A.E., Gunawardhana, P. \& Simpson, I.A. (2018), 'Hydraulic Complexities: Collapse and Resilience in Sri Lanka', in S. Federica \& I. Pikirayi (eds), Water and Society Resilience, Decline, and Revival from Ancient Times to the Present (Albuquerque, Routledge), 259-81.

Strickland, K.M., Coningham, R.A.E., Acharya, K.P., Schmidt, A., Simpson, I.A., Kunwar, R.B., Tremblay, J., Manuel, M.J., Davis, C.E., Krishna Bahadur, K.C. \& Bidari, B. (2016), 'Ancient Lumminigame: A Preliminary Report on Recent Archaeological Investigations at Lumbini's Village Mound (Nepal)', Ancient Nepal, 190: 1-17.

Tainter, J. (1990), The Collapse of Complex Societies (Cambridge, Cambridge University Press).

Thompson, J.E.S. (1966), The Rise and Fall of Maya Civilization, 2nd edn (Norman, University of Oklahoma Press).

Turner, B.L. \& Sabloff, J.A. (2012), 'Classic Period Collapse of the Central Maya Lowlands: Insights about Human-Environment Relationships for Sustainability', Proceedings of the National Academy of Sciences, 109: 13908-14.

Turner, B.L., Tidwell, V., Fernald, A., Rivera, J.A., Rodriguez, S., Guldan, S., Ochoa, C., Hurd, B., Boykin, K. \& Cibils, A. (2016), 'Modeling Acequia Irrigation Systems Using System Dynamics: Model Development, Evaluation, and Sensitivity Analyses to Investigate Effects of SocioEconomic and Biophysical Feedbacks', Sustainability, 8: 1-30.

UNFCCC (1995), United Nations Framework Convention on Climate Change (New York, UN). https:// unfccc.int/resource/ccsites/zimbab/conven/text/art01.htm

United Nations (2015), Resolution adopted by the General Assembly on 3 June 2015: 69/283. Sendai Framework for Disaster Risk Reduction 2015-2030. www.preventionweb.net/files/resolutions/ N1516716.pdf

UNDRR (2021), Disaster Risk Reduction in Nepal: Status Report 2019. (Bangkok, UNDRR). https:// reliefweb.int/sites/reliefweb.int/files/resources/68230_6nepaldrmstatusreport.pdf

UNDRR (2021), Terminology (Geneva, UNDRR). www.undrr.org/terminology/disaster-risk

Verardi, G. (1988), Harigaon Satya Narayana, Kathmandu: A Report on the Excavations Carried out in 1984-1988 (Rome, IsMEO).

Verardi, G. (2007), Excavations at Gotihawa and Pipri, Kapilbastu District, Nepal (Rome: IsIAO).

Weise, K. (2013), The Sacred Garden of Lumbini (Paris, UNESCO).

Weiss, H. (2016), 'Global Megadrought, Societal Collapse and Resilience at 4.2-3.9 ka BP across the Mediterranean and West Asia', Past Global Changes, 24(2): 62-3.

Wheeler, R.E.M. (1962), Charsada: A Metropolis of the North-West Frontier (Oxford, Oxford University Press). 
Wheeler, R.E.M. (1963), Early India and Pakistan (London, Thames \& Hudson).

Wheeler, R.E.M. (1966), Civilizations of the Indus Valley and Beyond (London, Thames \& Hudson).

Yoffee, N. (2005), Myths of the Archaic State: Evolution of the Earliest Cities, States and Civilizations (Cambridge, Cambridge University Press).

To cite the article: Robin Coningham and Lisa J. Lucero (2021), 'Urban infrastructure, climate change, disaster and risk: lessons from the past for the future', Journal of the British Academy, 9(s8): 79-114.

DOI https://doi.org/10.5871/jba/009s8.079

Journal of the British Academy (ISSN 2052-7217) is published by

The British Academy, 10-11 Carlton House Terrace, London, SW1Y 5AH

www.thebritishacademy.ac.uk 